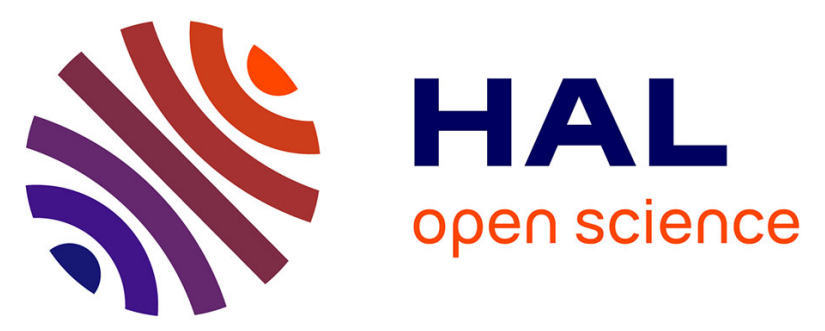

\title{
On the long-lasting sequences of coral reef terraces from SE Sulawesi (Indonesia): Distribution, formation, and global significance
}

Kevin Pedoja, Laurent Husson, Antoine Bézos, Anne-Morwenn Pastier, Andy Muhammad Imran, Camilo Arias-Ruiz, Anta-Clarisse Sarr, Mary Elliot, Edwige Pons-Branchu, Maëlle Nexer, et al.

\section{To cite this version:}

Kevin Pedoja, Laurent Husson, Antoine Bézos, Anne-Morwenn Pastier, Andy Muhammad Imran, et al.. On the long-lasting sequences of coral reef terraces from SE Sulawesi (Indonesia): Distribution, formation, and global significance. Quaternary Science Reviews, 2018, 188, pp.37-57. 10.1016/j.quascirev.2018.03.033 . hal-01983439

\section{HAL Id: hal-01983439}

\section{https://hal-normandie-univ.archives-ouvertes.fr/hal-01983439}

Submitted on 26 Jul 2019

HAL is a multi-disciplinary open access archive for the deposit and dissemination of scientific research documents, whether they are published or not. The documents may come from teaching and research institutions in France or abroad, or from public or private research centers.
L'archive ouverte pluridisciplinaire HAL, est destinée au dépôt et à la diffusion de documents scientifiques de niveau recherche, publiés ou non, émanant des établissements d'enseignement et de recherche français ou étrangers, des laboratoires publics ou privés. 


\title{
On the long-lasting sequences of coral reef terraces from SE Sulawesi (Indonesia): Distribution, formation, and global significance
}

\author{
Kevin Pedoja a,b,c,*, Laurent Husson ${ }^{\mathrm{d}}$, Antoine Bezos ${ }^{\mathrm{e}}$, Anne-Morwenn Pastiere, \\ Andy Muhammad Imran ${ }^{\mathrm{f}}$, Camilo Arias-Ruize, Anta-Clarisse Sarr ${ }^{\mathrm{d}}$, Mary Elliot ${ }^{\mathrm{e}}$, \\ Edwige Pons-Branchug, Maëlle Nexera, a,b, Vincent Regard ${ }^{\mathrm{h}, \mathrm{i}, \mathrm{j}}$, Abdul Hafidz, \\ Xavier Robert ${ }^{\mathrm{d}}$, Laurent Benoit ${ }^{\mathrm{a}, \mathrm{b}, \mathrm{c}}$, Bernard Delcaillau ${ }^{\mathrm{a}, \mathrm{b}, \mathrm{c}}$, Christine \\ Authemayou $^{\mathrm{k}}$, Caroline Dumoulin ${ }^{\mathrm{d}}$, Gaël Choblet ${ }^{\mathrm{d}}$
}

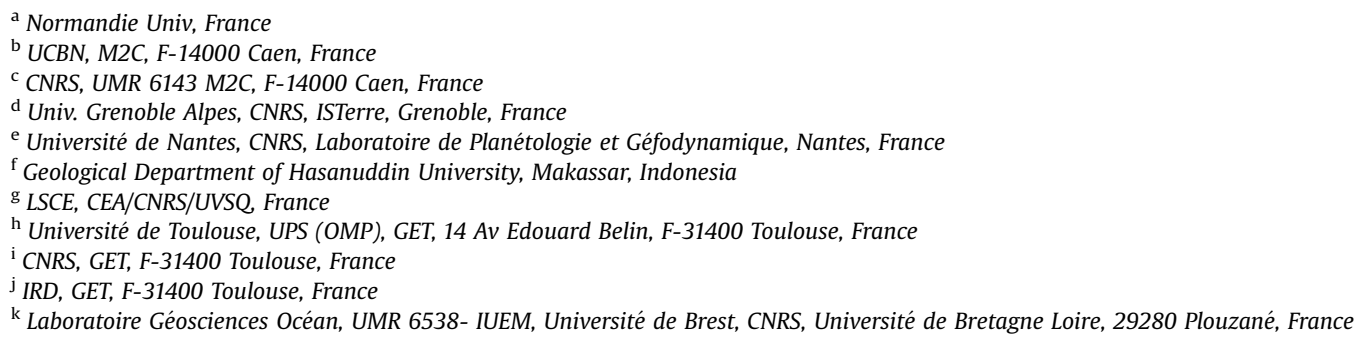

\begin{abstract}
Many islands of the eastern Indonesian Archipelago exhibit Late Cenozoic sequences of coral reef terraces. In SE Sulawesi, on the Tukang Besi and Buton archipelagos, we identified 23 islands bearing such sequences. Remote sensing imagery and field mapping combined to $\mathrm{U} / \mathrm{Th}$ and ${ }^{14} \mathrm{C}$ dating enable to establish a chronologic framework of the reef terrace sequences from Wangi-Wangi, Buton as well as on the neighbouring, smaller islands of Ular, Siumpu and Kadatua. We identified the terraces from the last interglacial maximum (MIS 5e) at elevations lower than $20 \mathrm{~m}$ except on W Kadatua where it is raised at $34 \pm 5 \mathrm{~m}$. Such elevations yield low to moderate Upper Pleistocene uplift rates $\left(<0.3 \mathrm{~mm} \mathrm{yr}^{-1}\right)$. On SE Buton Island, a sequence culminates at $650 \mathrm{~m}$ and includes at least 40 undated strandlines. Next to this exceptional sequence, on the Sampolawa Peninsula, 18 strandlines culminate at $430 \mathrm{~m}$. Dated samples at the base of this sequence $(<40 \mathrm{~m})$ yield mean Middle Pleistocene uplift rates of $0.14 \pm 0.09 \mathrm{~mm} \mathrm{yr}^{-1}$. Extrapolation of these uplift rates compared to the geological setting suggests that the sequences of the Sampolawa Peninsula provide a record of sea-level high-stands for the last $3.8 \pm 0.6 \mathrm{Ma}$. The sequences on SE Buton Island therefore constitute the best preserved long-lasting geomorphic record of PlioQuaternary sea-level stands worldwide.
\end{abstract}

\section{Introduction}

Morphologic evidence of late Cenozoic sea-level changes mostly documents Middle and Upper Pleistocene times (Guilcher, 1969; Johnson and Libbey, 1997; Siddal et al., 2006; Bowen, 2010; Pedoja

\footnotetext{
* Corresponding author. Normandie Univ, France.

E-mail address: kevin.pedoja@unicaen.fr (K. Pedoja).
}

et al., 2011, 2014; Murray-Wallace and Woodroffe, 2014; Rovere et al., 2016). In fact, little is known about interglacials older than Marine Isotopic Stage 11 (MIS 11, 360-420 ka); their timing, duration and number of high-stands would have remained unknown if isotope records were not partly alleviating our lack of knowledge (Emiliani, 1955; Shackleton, 1987; Waelbroeck et al., 2002; Lisiecki and Raymo, 2005; Bintanja and Van de Wal, 2008; Zachos et al., 2008; Rohling et al., 2009). Sequences of coral reef terraces are widespread tropical indicators of ancient sea levels 

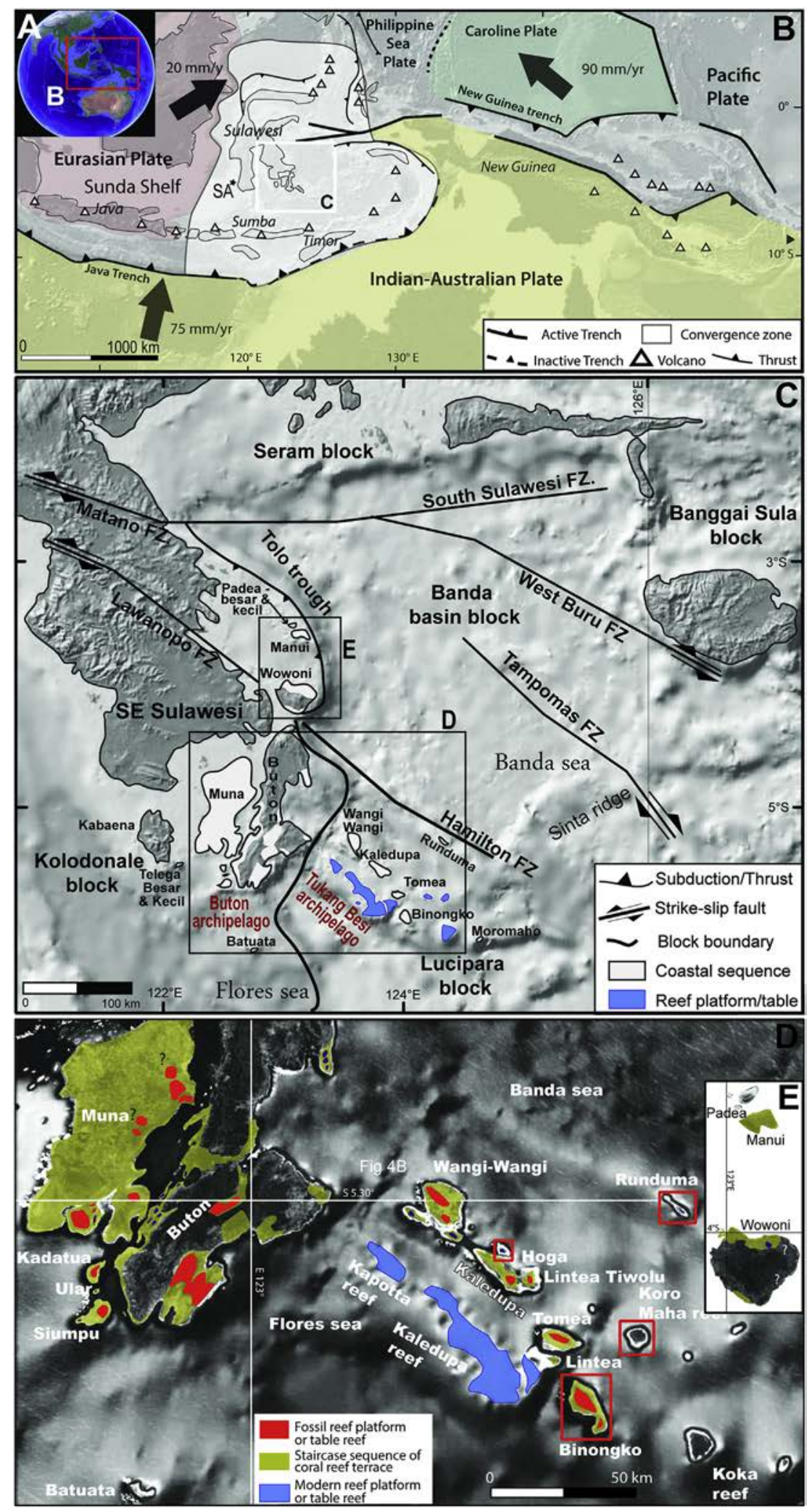

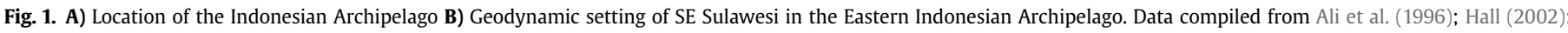

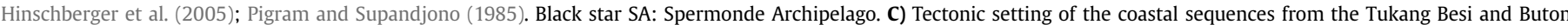

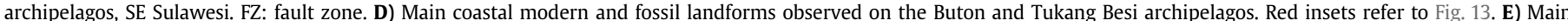

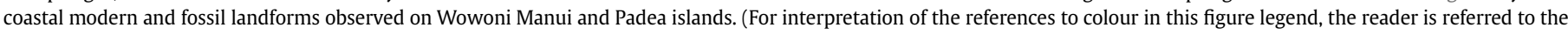
Web version of this article.) 
(e.g., Lyell, 1830; Darwin, 1842; Daly, 1915, 1925; Berry et al., 1966; Broecker et al., 1968; Hibbert et al., 2016). Classic sites span the last 1 Ma (Sumba Island in Indonesia, Barbados Island) where only Upper and Middle Pleistocene terraces are dated (Pirazzoli et al., 1991, 1993; Radtke et al., 1988; Schellmann and Radtke, 2004). Finally, the famous Huon Peninsula in Papua New Guinea provides a detailed record of sea-level changes since MIS 5e (see concise site descriptions in Murray-Wallace and Woodroffe, 2014 and reference therein).

We describe a unique set of emerged sequences of marine and coral reef terraces from SE Sulawesi, which is a promising feature for understanding and reconstructing Lower Pleistocene and Upper Pliocene sea levels. Late Cenozoic slow to moderate uplift of SE Sulawesi led to the formation and preservation of spectacular sequences of strandlines (Satyana and Purwaningsih, 2011) that record the uplift of eastern Indonesia, an area that belongs to a larger region named the Maritime Continent (Molnar and Cronin, 2015). These sequences have been mentioned and briefly described (Verbeek, 1908; Fortuin et al., 1990; Tomascik, 1997; Satyana and Purwaningsih, 2011; Nugraha and Hall, 2018) but no chronologic framework has been proposed. Based on $13 \mathrm{U}$-series and $7{ }^{14} \mathrm{C}$ dates, we propose age constraints for the sequences located on the Tukang Besi and Buton archipelagos. We derive uplift rates on dated terraces, which we extrapolate to estimate the age of the sequences, and discuss these features within the geological framework of the area. Finally, we provide a general description of the late Cenozoic palaeogeographical evolution of the archipelagos and compare our results to other long-lasting sequences of emerged reef worldwide.

\section{Settings}

\subsection{Regional geology}

SE Sulawesi is surrounded by the Banda and Flores seas, where multiple islands cluster in the Buton and Tukang Besi archipelagos (Fig. 1). The Tukang Besi archipelago rests atop the Lucipara continental block, and is gradually colliding with the Kolodonale block that hosts the Buton Archipelago. Both blocks derive from the Bird's Head, a former fragment of the Australian plate now accreted to NE Papua (Hall, 2002), from which they detached during the separation of Gondwana (Pigram and Supandjono, 1985). During Oligocene and Miocene times, the Kolodonale block collided with Sulawesi, followed by the Lucipara Block (Hinschberger et al., 2005). Paleomagnetic data (Ali et al., 1996) suggest that collision took place during Pliocene times ( $\sim 3 \mathrm{Ma}$ ) while more general plate reconstructions suggest an onset of collision at $\sim 13 \mathrm{Ma}$ (Hinschberger et al., 2005). This continental collision belongs to a larger convergent system that incorporates the oceanic Banda Basin, which is subducting underneath SE Sulawesi along the Tolo trough (Fig. 1B).

Pre-collisional rocks crop out in the centre of Buton Island, while the rest of the island is made of syn-collisional formations (Fortuin et al., 1990). The Tondo Fm. (11-7 Ma) is coarsening-upwards from silts to coarse bioclastic limestones. The Sampolakosa Fm. (7-3 Ma) is constituted at its base by chalk marls and at its top by reef limestone debris (Fortuin et al., 1990). The most recent Wapulaka Fm. developed as a veneer of reef limestone, formed by sequences of coral and marine terraces (Fortuin et al., 1990; Satyana and Purwaningsih, 2011; Nugraha and Hall, 2018). The Wapulaka

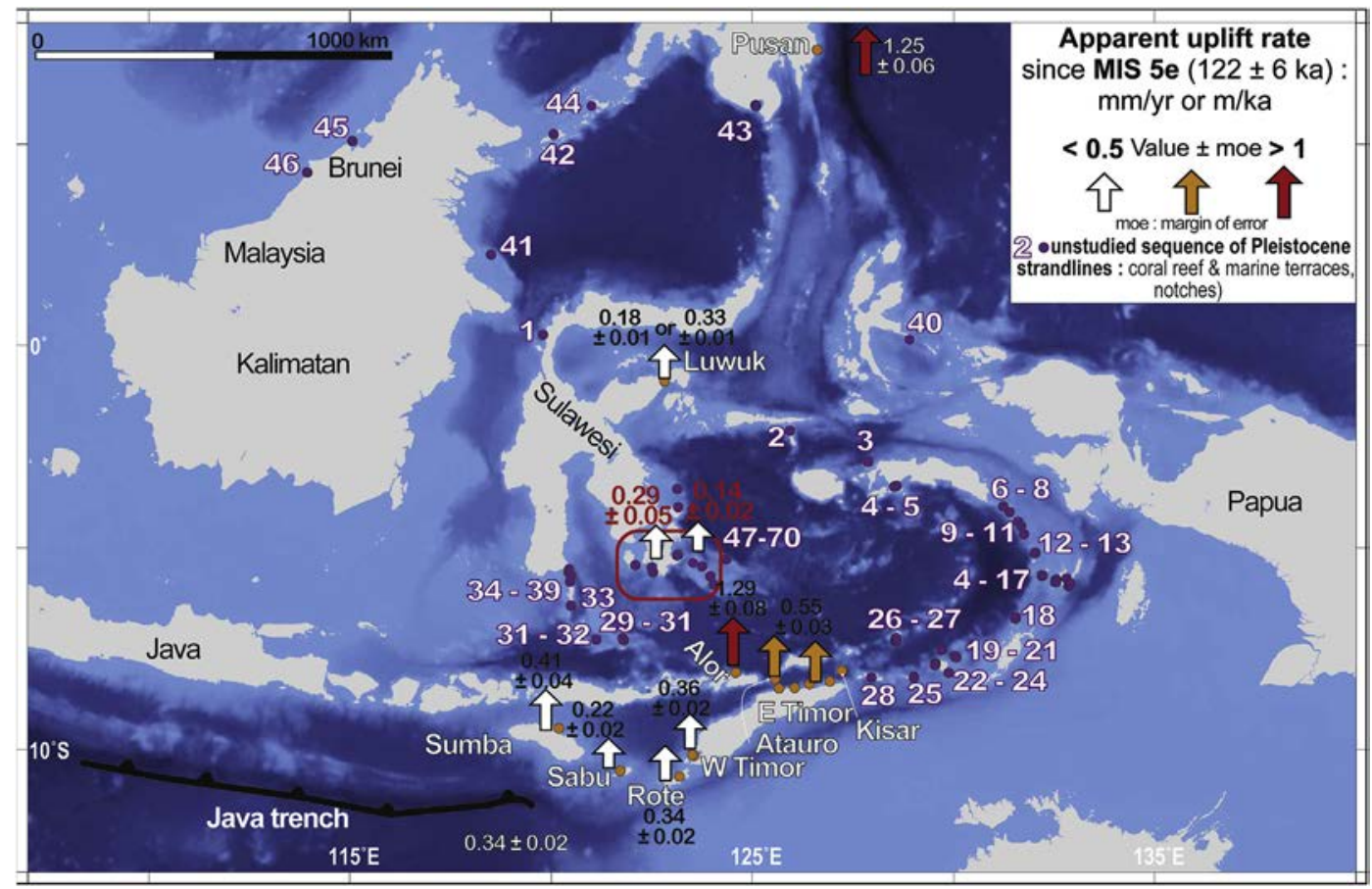

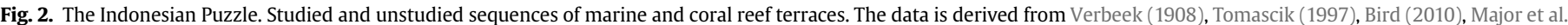

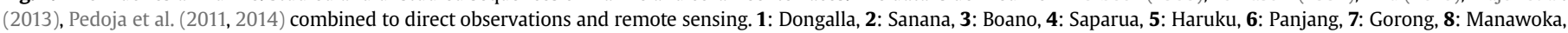

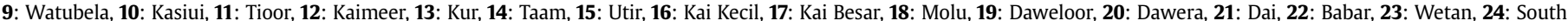

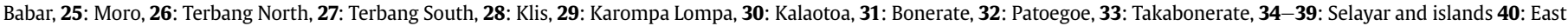

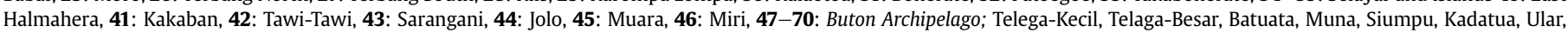

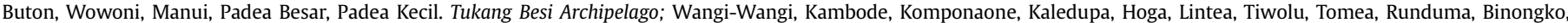

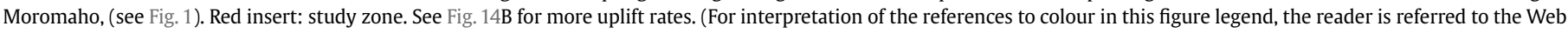
version of this article.) 
formation is proposed to have formed within the planktonic foraminifera zones N21-N22/23 (Fortuin et al., 1990; Satyana and Purwaningsih, 2011). The zone N21 ranges from $\sim 4.4 \mathrm{Ma}$ to $\sim 1 \mathrm{Ma}$ (Hilgen et al., 2012) whereas zones N22/23 span the last $1 \mathrm{Ma}$ (Pillans et al., 2012).

The Tukang Besi archipelago (Fig. 1B and C) exhibits a wide array of reef morphologies, from platform and table reefs to fringing and barrier reefs (Satyana and Purwaningsih, 2011). All the islands are either totally (e.g., Wangi-Wangi, Binongko) or partially (e.g. Kaledupa) covered by sequences of coral and marine terraces and associated notches.

\subsection{Coastal sequences of Indonesia}

Sequences of marine and coral reef terraces are described on the eastern islands of the Indonesian Archipelago, north of the area where the Australian continent is colliding with the Banda Arc (Hantoro, 1992; Merritts et al.,1998; Major et al., 2013; Pedoja et al., 2014; Molnar and Cronin, 2015). Dated terraces are described within coastal sequences on the islands of Sumba (Hantoro, 1992; Pirazzoli et al., 1991, 1993), Alor (Hantoro et al., 1994), Sabu and Roté (Roosmawati and Harris, 2009), Atauro and Timor (Chappell and Veeh, 1978; Jouannic et al., 1988) and Kisar (Major et al., 2013) (Fig. 2). On Gunung Dirun (W Timor) a coastal sequence reaches
1293 m in elevation (Tomascik, 1997; Cabioch, 2011), which constitutes, to our knowledge, the highest elevation for such landform worldwide. In Eastern Indonesia, Upper Pleistocene (MIS 5e) strandlines are uplifted from $158 \pm 7 \mathrm{~m}$ (Alor Island; Merritts et al., 1998; Hantoro et al., 1994) to $27.5 \pm 2.5 \mathrm{~m}$ (Sabu Island, Hantoro, 1992) which yields apparent coastal uplift rates from $1.29 \pm 0.08 \mathrm{~mm} \mathrm{yr}^{-1}$ to $0.22 \pm 0.02 \mathrm{~mm} \mathrm{yr}^{-1}$ respectively (Fig. 2). North of the Australia - Banda Arc collision, uplift decreases (even if the elevation of MIS 5e is not well established at Luwuk, E Sulawesi) (Sumosusastro et al., 1989, Fig. 2). Following Verbeek (1908), Bird (2010) and Major et al. (2013), we identified at least 70 islands in Indonesia, where poorly studied coastal sequences could potentially complement our investigations. Most of them are located in the eastern part of the archipelago (Fig. 2).

In SE Sulawesi, Verbeek (1908) first sketched the staircase coastal landscapes of Wangi-Wangi Island and of the Sampolawa Peninsula (SE Buton). Kuenen (1933) analyzed the bathymetry of the Tukang Besi archipelago. Tjia et al. (1974) mentioned a sequence of 14 terraces on Tomea Island (Tukang Besi Archipelago) and focused on the lowest terrace (see below). Fortuin et al. (1990) described 14 terraces on the Sampolawa Peninsula (SE Buton). In SW Buton, a coral sample collected from a terrace at $92 \mathrm{~m}$ in elevation yielded a U/Th age of $182 \pm 27$ ka (Fortuin et al., 1990). Finally, Satyana and Purwaningsih (2011) provided a distribution of

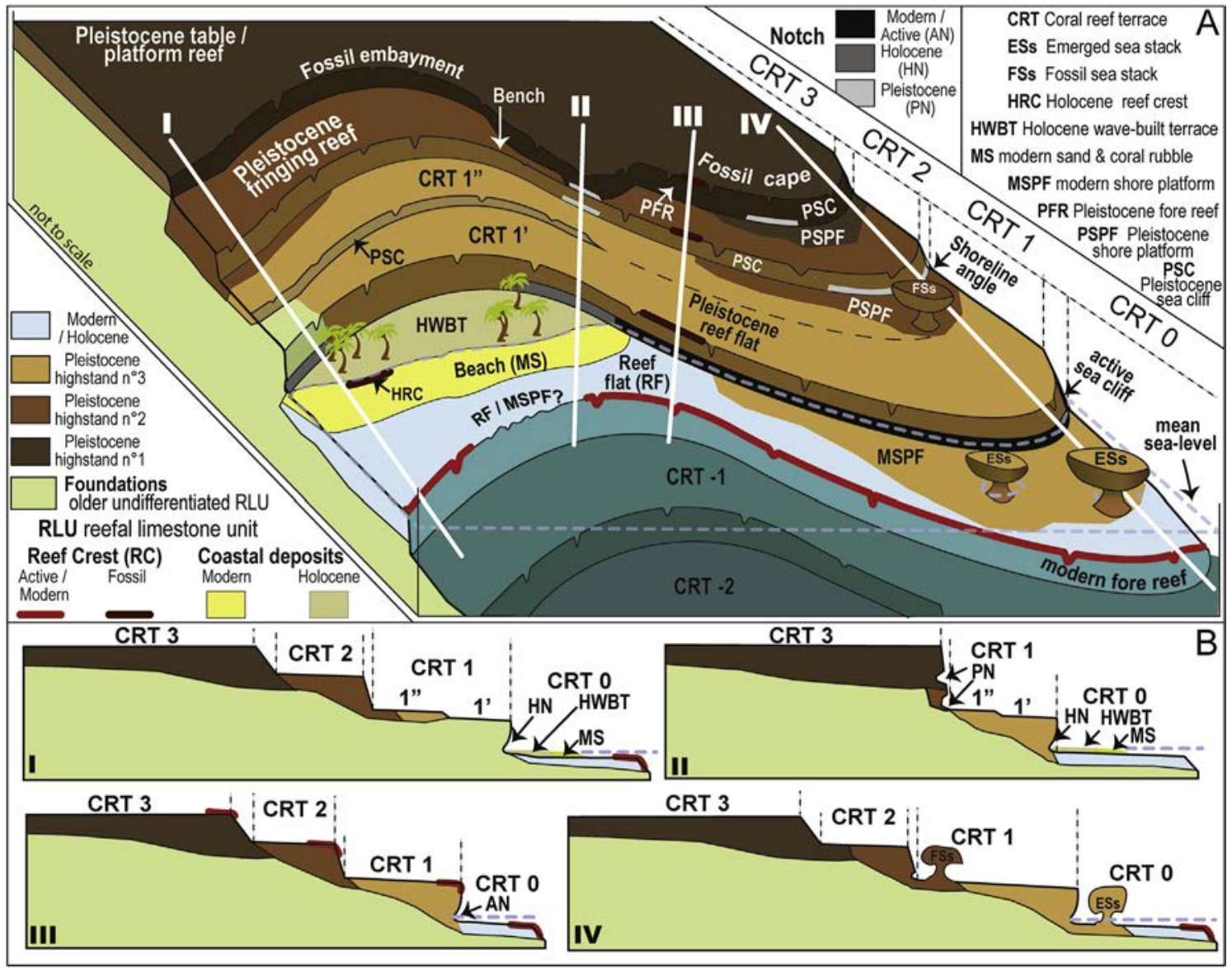

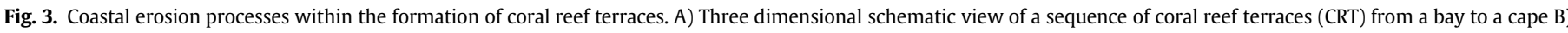

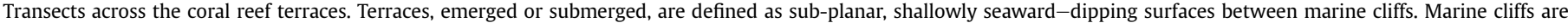

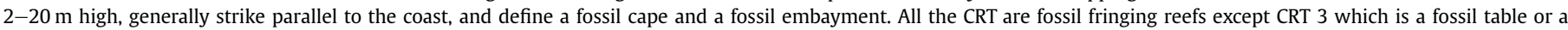

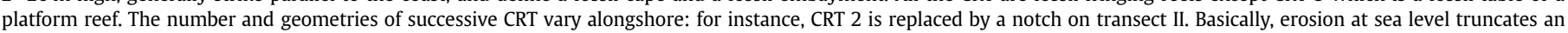

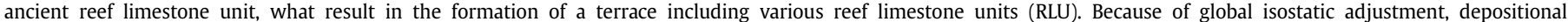

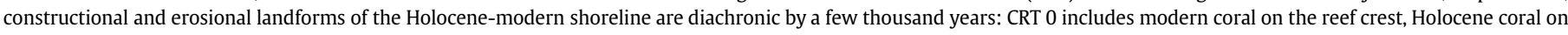
the reef flat and on the upper tidal area. Locally the Holocene reef is overlaid by younger Holocene deposits from the wave-built terrace (HWBT). 
the uplifted coasts of Sulawesi that includes brief morphological descriptions of Wangi-Wangi and SE Buton.

Regional variability of sea-level changes since the Last Glacial Maximum ( $20 \mathrm{ka} B P$ ) results from the combination of glacioisostatic adjustment (GIA), tectonics and other local processes (Shennan and Horton, 2002; Milne et al., 2005; Lambeck et al., 2012, 2014). Variable regional timings of the mid-Holocene highstand in Tropical Pacific sea level are reflected by frequent discrepancies in calibrated radiocarbon ages for emergent midHolocene fossil reefs (Dickinson, 2001; Woodroffe and Horton, 2005), that can readily be attributed to GIA (Mitrovica and Milne, 2003). On Tomea (Tukang Besi Archipelago, Fig. 1B), Tjia et al. (1972, 1974) radiocarbon dated a mollusc shell from a terrace whose shoreline now stands at $10 \mathrm{~m}$. The shells, that yielded an age of $1120 \pm 90 \mathrm{yr}$, were collected in crevices of the coral reef terrace. The authors correlated the wide, low-lying terrace to the Holocene and calculated an uplift rate of $8.4 \mathrm{~mm} \mathrm{yr}^{-1}$ (Tjia et al., 1972). At various sites from the Spermonde archipelago (Fig. 1A), off the Southwest Sulawesi Peninsula, $320 \mathrm{~km}$ westward of Buton, the amplitude of the GIA was more recently re-evaluated to be less than $+1 \mathrm{~m}$ instead of the $+5 \mathrm{~m}$ previously estimated (see Mann et al., 2016 and reference therein).

\section{Emerged sequences of tropical strandlines and estimates of tectonics uplift}

Marine and coral reef terraces, emerged in sequences, are stacked fingerprints of the course of sea-level changes on rising coasts (e.g., Lajoie, 1986). These fingerprints are associated to interglacial sea-level high-stands (associated to odd-numbered MIS), and well recognized throughout the Quaternary (MurrayWallace and Woodroffe, 2014). When a terrace is dated, its shoreline angle provides a good approximation to the location and elevation of a former strandline and, hence, a marker for relative sea level (Lajoie, 1986; Speed and Cheng, 2004). Sometimes, only the altitude of the fossil reef or the fossil shore platform can be determined and be used as a sea-level indicator (as in Mangaia Island, Cook islands, Ward et al., 1971).

\subsection{Marine terraces and coral reef terrace revisited}

Most geomorphic definitions formally distinguish marine terraces from coral reef terraces (van de Plassche, 1986; Pirazzoli, 1994; Pedoja et al., 2011; Murray-Wallace and Woodroffe, 2014). Marine terraces result from the effects of marine erosion (also called wave-cut terraces or fossil shore platforms) and accumulation of sediments at shallow depths (wave-built terraces) (Pirazzoli, 2005a; b). The shoreline angle of a terrace corresponds to the intersection of the platform with the sea cliff (Fig. 3; Lajoie, 1986). Notches are horizontal incisions in cliffs (Fig. 3) with widths and excavation depths that reach up to a few metres. Notch types reflect a continuum from wave notches that form under quiet conditions at sea level to surf notches that form as much as $2 \mathrm{~m}$ above sea level (Pirazzoli, 1994). In inter-tropical regions, coral reefs are present and fossilized as coral reef terraces (Chappell, 1974) sometimes also called emerged reef, reef terraces (Hopley, 2005; Cabioch, 2011), or elevated reefs (Darwin, 1842). A coral reef terrace (CRT on Fig. 3) results from the combination of bioconstruction, erosion at sea level and subsequent accumulation of the eroded sediments (Pirazzoli, 2005a; b; Cabioch, 2011). It corresponds to a reef flat, or a reef platform. i.e., a stony expanse of reef rock with a flat surface (Pirazzoli, 2005a; b). Most generally, this surface is limited seaward by a frontal crest and a fore reef, and landward by a break in slope and a shoreline angle, sometimes underlined by a notch (Cabioch, 2011), and a fossil shore platform (i.e. a marine terrace, this study).
Besides some exceptions (Bloom et al., 1974; Stoddart and Spencer, 1987; Pirazzoli et al., 1993; Blanchon and Eisenhauer, 2000; Speed and Cheng, 2004; Montaggioni and Braithwaite, 2009; Cabioch, 2011), coastal erosion which results in the formation of rocky-shore platforms, notches, and visors (the modern equivalent of a marine terrace), during the formation of coral reef terraces, is largely underestimated. De facto, since the seminal works on the Huon Peninsula (Papua New Guinea; Bloom et al., 1974; Chappell, 1974) many studies simply postulate that a coral reef terrace corresponds to a single reef limestone unit (RLU on Fig. 3). It is regarded as a single, most generally fringing reef, built during a transgression until the eustatic peak associated to a sealevel high-stand, and ignores the erosive counterpart. Such postulate allows to use the reef crest of a fossil fringing reef as a tectonic benchmark (e.g. Lecolle et al., 1990) compared to the shoreline angle of the terrace as used in this study.

The various interplays between construction, deposition and erosion that we observed alongshore many islands of the Indonesian archipelago (SE and SW Sulawesi, Spermonde, Belitung, Sumba, Bali, Lembogan, Lombok ...) are synthesized on Fig. 3. Reef

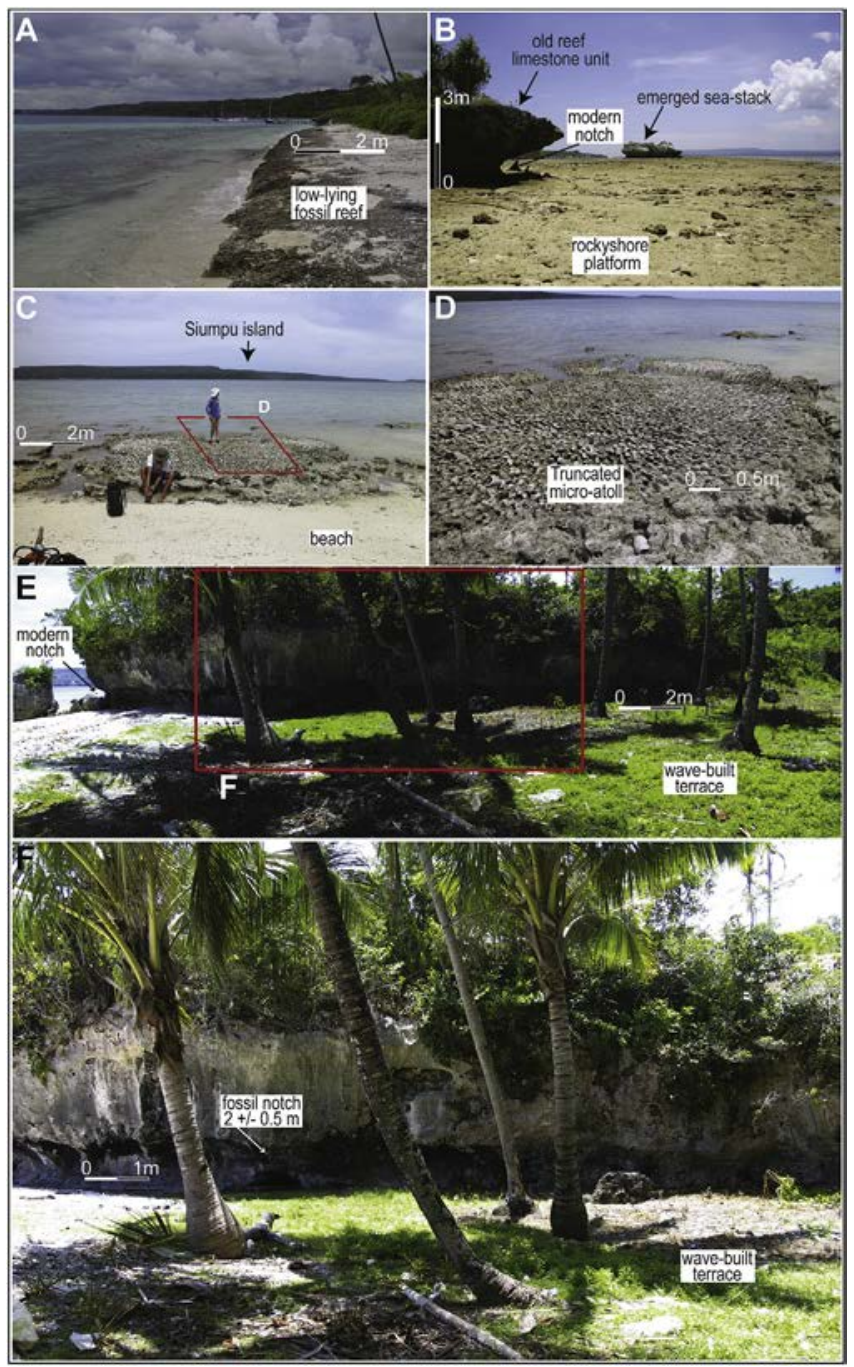

Fig. 4. The Holocene coastal record. A) Holocene reef, W Siumpu. B) Shore platform, notch and sea-stack, W Kadatua. See also Fig. 8D where the same sea-stack is shown on an air picture. C) and D) Fossil microatoll, Ular. E) and F) Modern - Holocene notch, west Bahari village. Location on Fig. 11A. Numbers correspond to the elevations (in metres) above the mean sea level. 


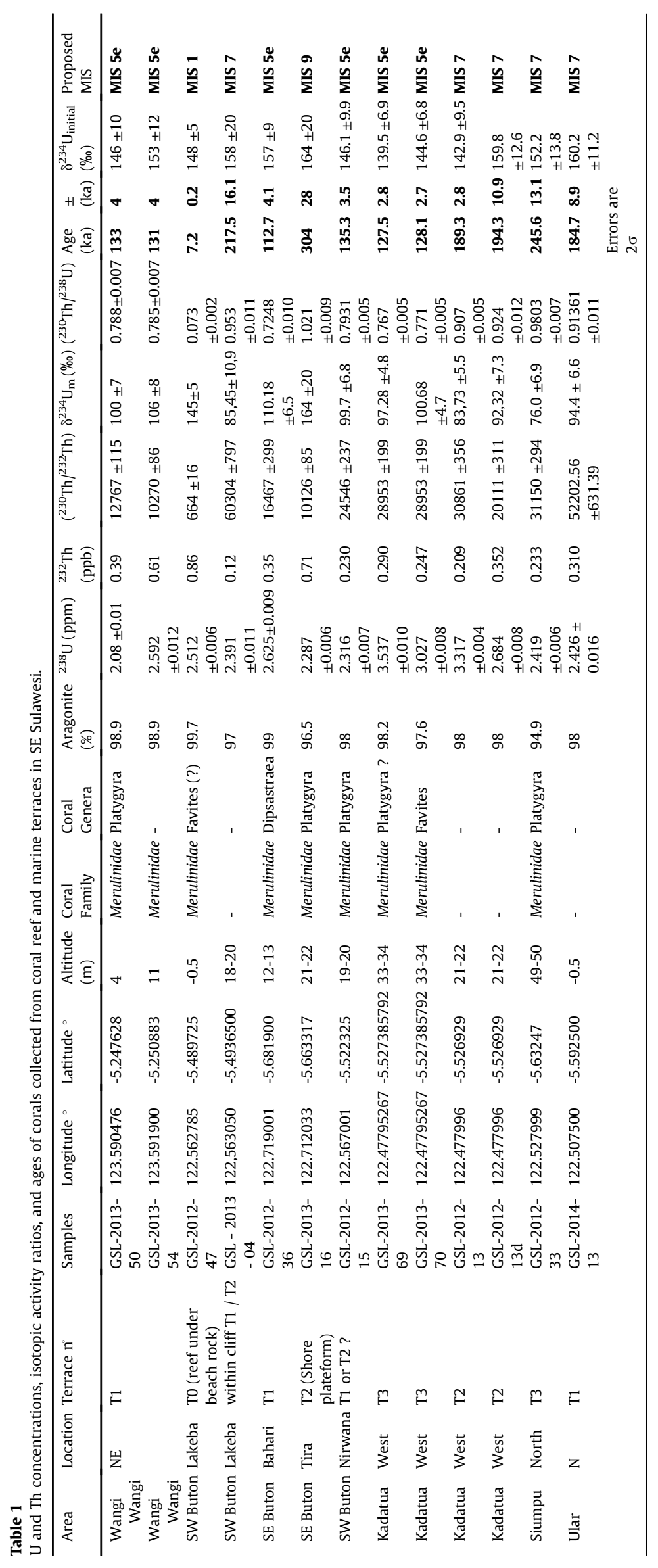


crests and reef flats are not always present alongshore. Some stretches are carved into notches and shore platforms, others include beaches, estuaries, mangroves ... When present, the fossil record exhibits the same alongshore variations of erosional landforms, deposits and construction whose gradual demise becomes more obvious as coastal landforms age (section 4.1).

During a given sea-level high-stand, the reef limestone unit is discontinuous alongshore. Moreover, such units are prone to erosion after their deposition, specifically at sea level, and many tropical rocky shores are carved into more ancient reef limestone. In SE Sulawesi, the surface of coral reef terraces are eroded, as highlighted by the truncation of underlying strata (Fig. 4) and the occurrence of fossil sea stacks, as described elsewhere (Speed and Cheng, 2004). In other words, within a sequence of coral reef terraces, the subsurface distribution and thickness of the various reef limestone units are not accessible directly on field. This lack of knowledge has strong implications for age determinations: a terrace can be associated to more than one reefal limestone unit thus host samples of multiple ages (see Fig. 3 for more details).

\subsection{Mapping method}

We mapped the studied coastal sequences based on field observations complemented by satellite imagery (Landsat, Spot, SRTM). We measured the elevations of fossil shoreline angles with barometric altimeters and/or differential GPS (dGPS, Trimble XT). Barometric altimeters were used mostly for the low-lying terraces that we surveyed repeatedly (3-5 measurements). We tied the elevations to modern sea level, as defined by the retreat point of the modern notch or by the last high-tide mark. Beside instrumental errors, we assigned a margin of error to all field measurements. The natural rugosity of the landforms is the main source of error; far beyond instrumental errors. The roughness of the landforms increases with elevation and age. For low standing landforms, the margin of error is set to $\pm 2 \mathrm{~m}$ whereas for upper strandlines it reaches $\pm 10 \mathrm{~m}$ because of increased erosion and karstification with altitude.

\section{3. $U /$ Th and ${ }^{14} \mathrm{C}$ dating}

Fossil coral colonies (Merulinidae fm.; Favites sp., Dipsastraea sp. Platygyra sp.), found in life-position on the terrace of the studied sequences were sampled with a portable core drill device. Thin sections of the selected corals were first inspected with a microscope to discard recrystallized portions. Thirteen selected samples were crushed into chips of $0.5-1 \mathrm{~cm}$ and mechanically cleaned. The coral samples were rinsed in milliQ water multiple times and leached in $0.1 \mathrm{~N}$ bi-distilled $\mathrm{HCL}$ for $15-20 \mathrm{~min}$ in an ultrasonic bath. The cleaned samples were crushed into powder and X-rayed at the ISTerre facility (Grenoble, France) to quantify the extent of calcite recrystallization if any. Sample powders were weighed
$500 \mathrm{mg}$ and spiked with a mixture of ${ }^{229} \mathrm{Th},{ }^{233} \mathrm{U}$ and ${ }^{236} \mathrm{U}$ prior to dissolution in $6 \mathrm{~N} \mathrm{HCl}$ at $100^{\circ} \mathrm{C}$. The fractions of Th and $\mathrm{U}$ were separated using the simplified UTEVA column chemistry method from Douville et al. (2010). The required ${ }^{238} \mathrm{U},{ }^{232} \mathrm{Th}$ concentrations and U-Th isotopic compositions for U-series disequilibrium dating were measured on the ICP-MS quadrupole mass spectrometer Thermo Fisher Scientific X series II at the Laboratory for Climate and Environment Sciences (LSCE, Gif-sur-Yvette, France) as described in Douville et al. (2010). Table 1 presents the analytical results. All coral samples display ${ }^{238} \mathrm{U}$ concentrations between 2 and $2.5 \mathrm{ppm}$. The low ${ }^{232} \mathrm{Th}$ contents together with high $\left({ }^{230} \mathrm{Th} /{ }^{232} \mathrm{Th}\right)$ activities ratios argue for the absence of significant detritical contamination. Most of the samples display initial $\delta^{234} U$ values that agree within errors with modern ocean water values of $\delta^{234} U=148 \pm 10$ (Chen et al., 1986; Cheng et al., 2000), which indicates isotopic Th-U evolution in a closed system.

Seven ${ }^{14} \mathrm{C}$ dating of Tridacnidae shells and corals from the lowermost terraces (Table 2) were performed at the Laboratoire de Mesure du Carbone 14 (LMC14). After removing any surface contamination by sand blasting the outer surface of shells and corals, the samples were cleaned with distilled water in an ultrasonic bath. The carbon isotopes were measured with the Artemis AMS facility of the LMC14. This facility is based on a 9SDH-2 Pelletron tandem from National Electrostatic Corporation. The procedure is extensively described in Dumoulin et al. (2017).

\subsection{Sea level curves and uplift rates}

Based on $\mathrm{U} / \mathrm{Th}$ and ${ }^{14} \mathrm{C}$ dating, we propose the morphostratigraphy and ranges of uplift rates deduced from the elevation of the marine terraces allocated to upper and middle Pleistocene interglacials (MIS 5e and MIS 9). Eustasy-corrected uplift rates are given by dividing the difference between the present elevation of the shoreline angle and the eustatic sea level at its formation time by the age of the terrace (Lajoie, 1986). We compute, for reference, apparent uplift rates (Table 3 ) that neglect any a priori eustatic correction (as in Pedoja et al., 2011, 2014; Yildirim et al., 2013; Authemayou et al., 2016).

Several sea-level curves have been derived from the oxygen isotopic records (Shackleton, 1987; Waelbroeck et al., 2002; Lisiecki and Raymo, 2005; Bintanja and Van de Wal, 2008; Zachos et al., 2008; Rohling et al., 2009), but also from -or combined to-the geomorphologic record (Siddal et al., 2006; Murray-Wallace and Woodroffe, 2014). These sea-level curves often present discrepancies in the ages and magnitudes of the MIS (Table 3; see also Caputo, 2007; Murray-Wallace and Woodroffe, 2014), but there is a relative consensus on the succession of the most recent highstands. The most common high-stand in the geomorphological record is the last interglacial period, MIS 5 (Stirling et al., 1998; Pedoja et al., 2011; Murray-Wallace and Woodroffe, 2014), that includes three relative high-stands, MIS 5a ( $85 \pm 5 \mathrm{ka})$, MIS 5c

Table 2

${ }^{14} \mathrm{C}$ AMS ages from bivalve shells and corals recovered from coral reef and marine terraces in SE Sulawesi.

\begin{tabular}{|c|c|c|c|c|c|c|c|c|c|c|c|c|}
\hline Sample code & Field Name & Location & Terrace $\mathrm{n}^{\circ}$ & elevation (m) & Long $^{\circ}$ & Lat $^{\circ}$ & Nature & $\mathrm{mg}$ & $\mathrm{d} \mathrm{C} 13$ & $\mathrm{pMC}$ & Ages BP & $\pm(y r)$ \\
\hline SacA47852 & Lakeba 1 & Lakeba Beach & HT & 0 & 122.562667 & -5.490167 & Cora & 1.36 & 0.4 & $67.998 \pm 0.195$ & 3100 & 30 \\
\hline SacA47853 & Lakeba $2 \mathrm{~A}$ & Lakeba Beach & HT & 0 & 122.562917 & -5.488883 & Veneridae shells & 0.74 & 1.8 & $69.399 \pm 0.23$ & 2935 & 30 \\
\hline SacA47854 & Lakeba 2B & Lakeba Beach & HT & 0 & 122.562917 & -5.488883 & Tridacna hipopus & 1.05 & 0 & $69.451 \pm 0.224$ & 2930 & 30 \\
\hline SacA47855 & GSL16_44 & Ular Island & T0 & -0.5 & 122.513567 & -5.589567 & Tridacnidae & 1.46 & 0.4 & $91.128 \pm 0.212$ & 745 & 30 \\
\hline SacA47856 & GSL16_59 & Ular Island & T0 & -0.5 & 122.507567 & -5.592800 & Tridacnidae & 1.18 & -5.2 & $0.215 \pm 0.092$ & $>49300$ & 3400 \\
\hline SacA47857 & GSL16_50 & Ular Island & T0 & -0.5 & 122.508217 & -5.598817 & undetermined coral & 0.54 & -0.3 & $0.211 \pm 0.095$ & $>49500$ & 3600 \\
\hline SacA47858 & GSL16_53 & Ular Island & T0 & -0.5 & 122.507950 & -5.592700 & undetermined coral & 1.52 & -2.1 & pMC $<0.343$ & $>45600$ & - \\
\hline
\end{tabular}

HT: Holocene terrace.

T0: modern shore platform.

pMC: percent modern carbon. 
Table 3

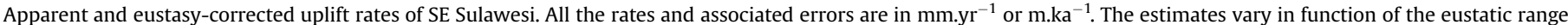

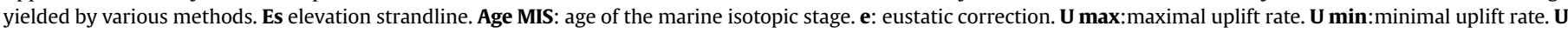
mean:mean uplift rate.

\begin{tabular}{|c|c|c|c|c|c|c|c|c|c|c|c|c|c|c|c|c|c|c|c|c|c|c|}
\hline \multirow[t]{3}{*}{ Location } & \multirow[t]{3}{*}{ Terrace } & \multirow{3}{*}{$\begin{array}{l}\text { Chrono- } \\
\text { stratigraphy }\end{array}$} & \multirow{2}{*}{\multicolumn{2}{|c|}{$\begin{array}{l}\text { Elevation } \\
\text { Strandline }\end{array}$}} & \multirow{2}{*}{\multicolumn{2}{|c|}{ Age MIS }} & \multirow{2}{*}{\multicolumn{4}{|c|}{$\frac{\text { This study }}{\text { Apparent uplift rates }}$}} & \multicolumn{6}{|c|}{ Murray-Wallace and Woodroffe, 2014} & \multicolumn{6}{|c|}{ Waelbroeck et al., (2002) a } \\
\hline & & & & & & & & & & & \multicolumn{2}{|c|}{$\begin{array}{l}\text { Eustatic } \\
\text { correction }\end{array}$} & \multicolumn{4}{|c|}{ Corrected uplift rate } & \multicolumn{2}{|c|}{$\begin{array}{l}\text { Eustatic } \\
\text { correction }\end{array}$} & \multicolumn{4}{|c|}{ Corrected uplift rate } \\
\hline & & & Es $(m)$ & $\pm(\mathrm{m})$ & $\begin{array}{l}\text { age } \\
\text { (ka) }\end{array}$ & $\begin{array}{l}\mathrm{MoE} \\
\text { (ka) }\end{array}$ & $\begin{array}{l}\mathrm{U} \max \\
(\mathrm{mm} / \mathrm{yr})\end{array}$ & $\begin{array}{l}\mathrm{U} \min \\
(\mathrm{mm} / \mathrm{yr})\end{array}$ & $\begin{array}{l}\text { U mean } \\
(\mathrm{mm} / \mathrm{yr})\end{array}$ & $\begin{array}{l} \pm \\
(\mathrm{mm} / \mathrm{yr})\end{array}$ & $\mathrm{e}(\mathrm{m})$ & $\pm(\mathrm{m})$ & $\begin{array}{l}\mathrm{U} \max \\
(\mathrm{mm} / \mathrm{yr})\end{array}$ & $\begin{array}{l}\mathrm{U} \min \\
(\mathrm{mm} / \mathrm{yr})\end{array}$ & $\begin{array}{l}\text { U mean } \\
(\mathrm{mm} / \mathrm{yr})\end{array}$ & $\begin{array}{l} \pm \\
(\mathrm{mm} / \mathrm{yr})\end{array}$ & $\mathrm{e}(\mathrm{m})$ & $\pm(\mathrm{m})$ & $\begin{array}{l}\mathrm{U} \max \\
(\mathrm{mm} / \mathrm{yr})\end{array}$ & $\begin{array}{l}\mathrm{U} \min \\
(\mathrm{mm} / \mathrm{yr})\end{array}$ & $\begin{array}{l}\text { U mean } \\
(\mathrm{mm} / \mathrm{yr})\end{array}$ & $\begin{array}{l} \pm \\
(\mathrm{mm} / \mathrm{yr})\end{array}$ \\
\hline Wangi Wangi & $\mathrm{T} 1$ & MIS 5e & 17 & 2 & 122 & 6 & 0.16 & 0.12 & 0.14 & 0.02 & 6 & 4 & 0.15 & 0.04 & 0.09 & 0.05 & 6 & 13 & 0.22 & -0.03 & 0.10 & 0.13 \\
\hline Kadatua & T3 & MIS 5e & 35 & 4 & 122 & 6 & 0.34 & 0.24 & 0.29 & 0.05 & 6 & 4 & 0.32 & 0.16 & 0.24 & 0.08 & 6 & 13 & 0.40 & 0.09 & 0.25 & 0.15 \\
\hline Nirwana & $\mathrm{T} 2$ & MIS 5e & 19 & 1 & 122 & 6 & 0.17 & 0.14 & 0.16 & 0.02 & 6 & 4 & 0.16 & 0.06 & 0.11 & 0.05 & 6 & 13 & 0.23 & -0.01 & 0.11 & 0.12 \\
\hline Bahari & $\mathrm{T} 1$ & MIS 5e & 15 & 2 & 122 & 6 & 0.15 & 0.10 & 0.12 & 0.02 & 6 & 4 & 0.13 & 0.02 & 0.08 & 0.05 & 6 & 13 & 0.21 & -0.05 & 0.08 & 0.13 \\
\hline Siumpu & T3 & MIS 7 & 54 & 2 & 218 & 27.5 & 0.29 & 0.21 & 0.25 & 0.04 & -8 & 12 & 0.40 & 0.20 & 0.30 & 0.10 & -4 & 13 & 0.38 & 0.18 & 0.28 & 0.10 \\
\hline Lakeba & $\mathrm{T} 2$ & MIS 7 & 33 & 2 & 218 & 27.5 & 0.18 & 0.13 & 0.16 & 0.03 & -8 & 12 & 0.29 & 0.11 & 0.20 & 0.09 & -4 & 13 & 0.27 & 0.09 & 0.18 & 0.09 \\
\hline Tira & T3 & MIS 9 & 38 & 4 & 325 & 18.5 & 0.14 & 0.10 & 0.12 & 0.02 & 3 & 2 & 0.13 & 0.08 & 0.11 & 0.02 & 5 & 13 & 0.16 & 0.05 & 0.11 & 0.06 \\
\hline
\end{tabular}

${ }^{a}$ Waelbroeck et al., (2002) built a composite relative sea level curve, over the last four climatic cycles, from long benthic isotopic records retrieved at one North Atlantic and one Equatorial Pacific site.

b Bintanja and Van der Wal, (2008) used an ice-sheet model and a simple ocean-temperature model to extract three-million-year mutually consistent records of surface air temperature, ice volume and sea level from marine benthic oxygen isotopes.

c Grant et al. (2014) proposed a chronology derived from a U/Th-dated speleothem d 180 record, for a continuous, high-resolution record of Red Sea relative sea level over five complete glacial cycles (500 kyr).

d Shakun et al., (2015) through a global compilation of 49 paired sea surface temperature-planktonic d 180 records extracted the mean d 180 of surface ocean seawater and eustatic curve over the past $800 \mathrm{kyr}$.

e Spratt and Lisiecki (2016) performed principal component analysis (PCA) on seven records from 0 to 430 ka and five records from 0 to 798 ka.

$(105 \pm 5 \mathrm{ka})$ and MIS $5 \mathrm{e}$ (128 ka to $116 \mathrm{ka})$. MIS 7 ranges from 190 to $245 \mathrm{ka}$ (Thompson and Goldstein, 2005), and includes sub-stages 7a (190-200 ka), 7c (206-217 ka) and 7e (231-248 ka) (Dutton et al., 2009). In Henderson Island, South Pacific, two sea-level high-stands have been observed during MIS 9: sub-stages 9a and 9c extending from $306 \pm 3 \mathrm{ka}$ to $334 \pm 4 \mathrm{ka}$ respectively (324.5 $\pm 18.5 \mathrm{ka})$ (Stirling et al., 2001). MIS 11 lasted from $420 \mathrm{ka}$ to 360 ka (Murray Wallace and Woodroffe, 2014). Earlier interglacial periods are MIS 13 (480-530 ka), MIS 15 (560-620 ka) and MIS 17 (650-720 ka) (Thompson et al., 2003; Andersen et al., 2008; Murray-Wallace and Woodroffe, 2014).

In order to account for the variability of sea-level curves, we analyzed the sequences of SE Sulawesi in the framework of the latest compilation of geomorphic indicators (Murray-Wallace and Woodroffe, 2014) but also with five eustatic curves (Table 3 , Waelbroeck et al., 2002; Bintanja and Van de Wal, 2008; Grant et al., 2014; Shakun et al., 2015; Spratt and Lisiecki, 2016). Murray-Wallace and Woodroffe (2014) consider that MIS 5e, MIS 7, MIS 9, and MIS 11 high-stands were respectively at $6 \pm 4 \mathrm{~m},-8 \pm 12 \mathrm{~m}, 3 \pm 2 \mathrm{~m}$, and $9.5 \pm 3.5 \mathrm{~m}$ with respect to present-day sea level (Table 3 ). The five sea-level curves were selected to encompass five different reconstruction methods, cover the time-range of interest (at least up to $420 \mathrm{ka}$ ) and have quantified uncertainties (see Table 3 for more details) (Waelbroeck et al., 2002; Bintanja and Van de Wal, 2008; Grant et al., 2014; Shakun et al., 2015; Spratt and Lisiecki, 2016). These different estimates of past sea levels translate into different estimates of uplift rates (Table 3) that are discussed section 5.2.

\section{The coastal sequences of SE Sulawesi}

Sequences of strandlines are present on at least 23 islands off SE Sulawesi, with the exception of Kabaena (Figs. 1C and 2). They either cover entire islands (Wangi-Wangi, Kadatua, Muna) or coastal stretches (Buton, Kaledupa or Wowoni) (Fig. 1C). The sequences often correspond to elevated reef platforms and table reefs bordered by staircase marine and coral reef terraces, which constitute elevated limestone islands (as defined in Schwartz, 2005).

\subsection{Holocene record}

At coastal sites of SE Sulawesi, we observed, at elevations from $\sim 0.5$ to $5 \mathrm{~m}$, an array of landforms and deposits, including notches, fossil coral reefs and coastal deposits ("wave-built deposits"). Low landforms are better preserved than their higher, older counterparts (Fig. 4A-D). Low-lying terraces are a few metres or a few tens of metres wide when higher terraces are reaching hundreds of metres wide. Coastal deposits such as coral rubble (HWBT in Fig. 3) are absent from high terraces that exhibit only eroded coral reef limestone. Finally, low-lying landforms form a morphological continuum toward the modern coast. For example, at the eastern and western tips of the Bahari embayment, the modern notch (the one reached by high tides) is morphologically continuous with a fossil notch, (buried with sand) (Fig. 4E and F) that reaches an elevation of $2 \pm 0.5 \mathrm{~m}$ to the west of the bay (see photogrammetric model at https://goo.gl/Ds4vWX).

To the SW of Buton Island (Figs. 5 and 6), at Lakeba, a low-lying sedimentary terrace, up to $40 \mathrm{~m}$ wide, backs up the modern beach. Sedimentary deposits are composed of poorly consolidated, shelly rudstones including coral rubbles. The terrace is bounded inland by a $\sim 3 \mathrm{~m}$ high cliff, sometimes associated to a $1.5-2 \mathrm{~m}$ high notch carved in an older reef limestone. Within the intertidal zone, below the rudstones, we observed in situ fossil corals that we interpreted as remnants of an emergent low-lying fossil reef which distal part is now located between spring and neap high tide marks (Fig. 6B). We sampled coral samples for $\mathrm{U} / \mathrm{Th}$ and ${ }^{14} \mathrm{C}$ dating. A fossil coral taken in the fossil reef exposed on the upper part of the sandy tidal flat of Lakeba, less than $20 \mathrm{~cm}$ below high-tide mark (Table 1, GSL-201247) was $U / T h$ dated. Tridacnidae and coral samples from the coastal deposits (Lakeba 1, 2A and B) (Table 2) were ${ }^{14} \mathrm{C}$ dated. GSL2012-47 yielded a U/Th age of $7.2 \pm 0.2$ ka whereas ${ }^{14} \mathrm{C}$-dated samples Lakeba $1,2 \mathrm{~A}$ and $2 \mathrm{~B}$ yielded ages of $3100 \pm 30 \mathrm{yr}$ $2935 \pm 30 \mathrm{yr}, 2930 \pm 30 \mathrm{yr}$ BP, respectively (Table 2 ). We relate the fossil, emergent, reef and the posterior deposits of the wave built terrace to Holocene GIA within the area.

Offshore SW Buton Island (Fig. 5), Ular is a small $(1.5 \times 0.5 \mathrm{~km})$, inhabited island. It is surrounded by a fringing reef that is backedup by a rocky-shore platform and associated notch along some part 


\begin{tabular}{|c|c|c|c|c|c|c|c|c|c|c|c|c|c|c|c|c|c|c|c|c|c|c|c|c|c|}
\hline \multicolumn{6}{|c|}{ Bintanja and Van der Wal, (2008) b } & \multicolumn{7}{|c|}{ Grant et al. (2014) c } & \multicolumn{6}{|c|}{ Shakun et al., (2015) d } & \multicolumn{7}{|c|}{ Spratt and Lisiecki (2016) e } \\
\hline \multicolumn{2}{|c|}{$\begin{array}{l}\text { Eustatic } \\
\text { correction }\end{array}$} & \multicolumn{4}{|c|}{ Corrected uplift rate } & \multicolumn{3}{|c|}{$\begin{array}{l}\text { Eustatic } \\
\text { correction }\end{array}$} & \multicolumn{4}{|c|}{ Corrected uplift rate } & \multicolumn{2}{|c|}{$\begin{array}{l}\text { Eustatic } \\
\text { correction }\end{array}$} & \multicolumn{4}{|c|}{ Corrected uplift rate } & \multicolumn{3}{|c|}{$\begin{array}{l}\text { Eustatic } \\
\text { correction }\end{array}$} & \multicolumn{4}{|c|}{ Corrected uplift rate } \\
\hline $\mathrm{e}(\mathrm{m})$ & $\pm(\mathrm{m})$ & $\begin{array}{l}\mathrm{U} \max \\
(\mathrm{mm} / \mathrm{yr})\end{array}$ & $\begin{array}{l}\mathrm{U} \min \\
(\mathrm{mm} / \mathrm{yr})\end{array}$ & $\begin{array}{l}\text { U mean } \\
(\mathrm{mm} / \mathrm{yr})\end{array}$ & $\begin{array}{l} \pm \\
(\mathrm{mm} / \mathrm{yr})\end{array}$ & $\mathrm{e}(\mathrm{m})$ & + & - & $\begin{array}{l}\mathrm{U} \max \\
(\mathrm{mm} / \mathrm{yr})\end{array}$ & $\begin{array}{l}\mathrm{U} \min \\
(\mathrm{mm} / \mathrm{yr})\end{array}$ & $\begin{array}{l}\text { U mean } \\
(\mathrm{mm} / \mathrm{yr})\end{array}$ & $\begin{array}{l} \pm \\
(\mathrm{mm} / \mathrm{yr})\end{array}$ & $\mathrm{e}(\mathrm{m})$ & $\pm(\mathrm{m})$ & $\begin{array}{l}\mathrm{U} \max \\
(\mathrm{mm} / \mathrm{yr})\end{array}$ & $\begin{array}{l}\mathrm{U} \min \\
(\mathrm{mm} / \mathrm{yr})\end{array}$ & $\begin{array}{l}\text { U mean } \\
(\mathrm{mm} / \mathrm{yr})\end{array}$ & $\begin{array}{l} \pm \\
(\mathrm{mm} / \mathrm{yr})\end{array}$ & $\mathrm{e}(\mathrm{m})$ & + & - & $\begin{array}{l}\mathrm{U} \max \\
(\mathrm{mm} / \mathrm{yr})\end{array}$ & $\begin{array}{l}\mathrm{U} \min \\
(\mathrm{mm} / \mathrm{yr})\end{array}$ & $\begin{array}{l}\text { U mean } \\
(\mathrm{mm} / \mathrm{yr})\end{array}$ & $\begin{array}{l} \pm \\
(\mathrm{mm} / \mathrm{yr})\end{array}$ \\
\hline 0 & 8 & 0.23 & 0.05 & 0.14 & 0.09 & 5 & 14 & 14 & 0.24 & -0.03 & 0.11 & 0.14 & -10 & 10 & 0.34 & 0.07 & 0.20 & 0.13 & 3 & 12 & 20 & 0.31 & 0.00 & 0.16 & 0.16 \\
\hline 0 & 8 & 0.41 & 0.18 & 0.29 & 0.11 & 5 & 14 & 14 & 0.41 & 0.09 & 0.25 & 0.16 & -10 & 10 & 0.51 & 0.22 & 0.37 & 0.14 & 3 & 12 & 20 & 0.48 & 0.13 & 0.30 & 0.18 \\
\hline 0 & 8 & 0.24 & 0.08 & 0.16 & 0.08 & 5 & 14 & 14 & 0.25 & -0.01 & 0.12 & 0.13 & -10 & 10 & 0.34 & 0.08 & 0.21 & 0.13 & 3 & 12 & 20 & 0.32 & 0.02 & 0.17 & 0.15 \\
\hline 0 & 8 & 0.22 & 0.04 & 0.13 & 0.09 & 5 & 14 & 14 & 0.22 & -0.05 & 0.09 & 0.14 & -10 & 10 & 0.32 & 0.05 & 0.19 & 0.13 & 3 & 12 & 20 & 0.29 & -0.02 & 0.14 & 0.15 \\
\hline$\# \#$ & 8 & 0.43 & 0.25 & 0.34 & 0.09 & -12 & 21 & 28 & 0.51 & 0.18 & 0.34 & 0.16 & -16 & 16 & 0.46 & 0.16 & 0.31 & 0.15 & -7 & 18 & 24 & 0.46 & 0.17 & 0.31 & 0.15 \\
\hline \#\# & 8 & 0.32 & 0.17 & 0.24 & 0.08 & -12 & 21 & 28 & 0.39 & 0.09 & 0.24 & 0.15 & -16 & 16 & 0.35 & 0.08 & 0.21 & 0.14 & -7 & 18 & 24 & 0.35 & 0.08 & 0.21 & 0.13 \\
\hline 0 & 8 & 0.16 & 0.08 & 0.12 & 0.04 & -10 & 10 & 15 & 0.22 & 0.10 & 0.16 & 0.06 & -27 & 18 & 0.28 & 0.07 & 0.18 & 0.11 & 3 & 15 & 30 & 0.23 & 0.05 & 0.14 & 0.09 \\
\hline
\end{tabular}

of the island coastal stretch (Fig. 6C and D). The island includes two terraces and a reef platform raised at $\sim 50 \mathrm{~m}$ (Fig. 6C and D). The lowermost terrace, to the east of the island, is mainly composed of wave-built coral rubbles up to $5 \pm 1 \mathrm{~m}$. This terrace is backed by a fossil notch. To the north of the island, there is a continuum between the fossil to the modern notch (see section 4.1). On the modern rocky shore platform, we sampled fossil corals and Tridacnidae for U/Th (GSL 2014-13) or ${ }^{14} \mathrm{C}$ dating (GSL 2016-44, GSL 2016-50, GSL 2016-53, GSL 2016-59; Table 2). GSL 2014-13 yielded a
U/Th age of $184.7 \pm 8.9 \mathrm{ka}$. GSL $2016-44$ (Tridacnidae) yielded $\mathrm{a}^{14} \mathrm{C}$ age of $0.745 \pm 0.030$ ka while GSL 201650,53 and 59 yielded ages that we interpret as minimum because at the limit of the method. Finally, we allocated the eroded reef unit and surrounding terrace to MIS 7 (Table 1). The carving of the platform is, of course, posterior, ranging from Holocene to modern time. Locally, the platform includes Tridacnidae shells or micro atolls developed on older reef units.

Our dating confirms the global observation (van de Plassche,

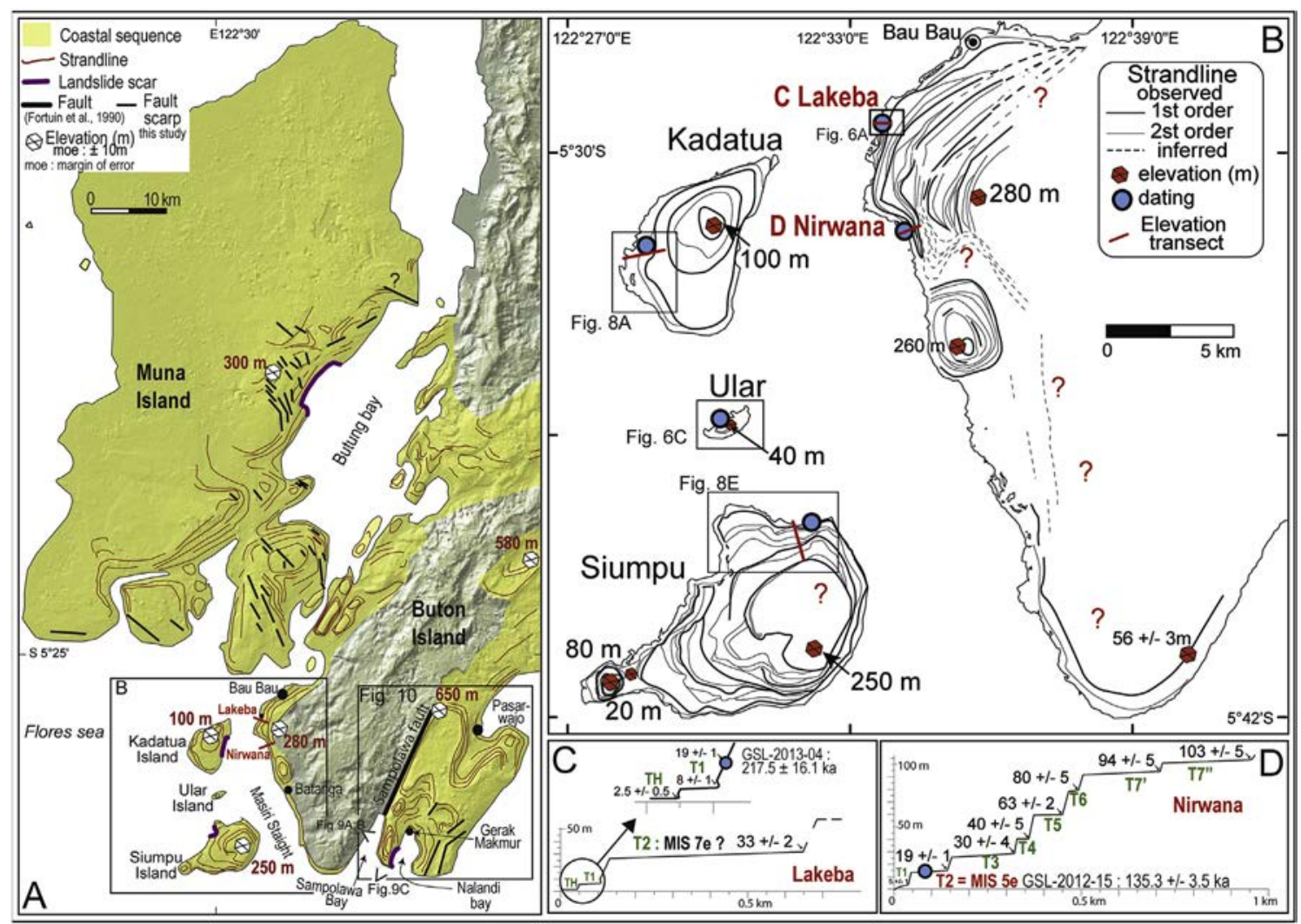

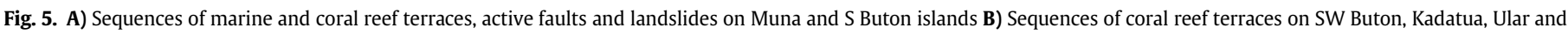

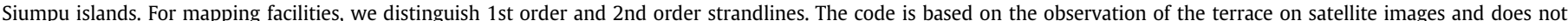

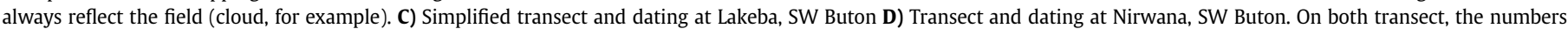
correspond to the elevations (in metres) above mean sea level. 


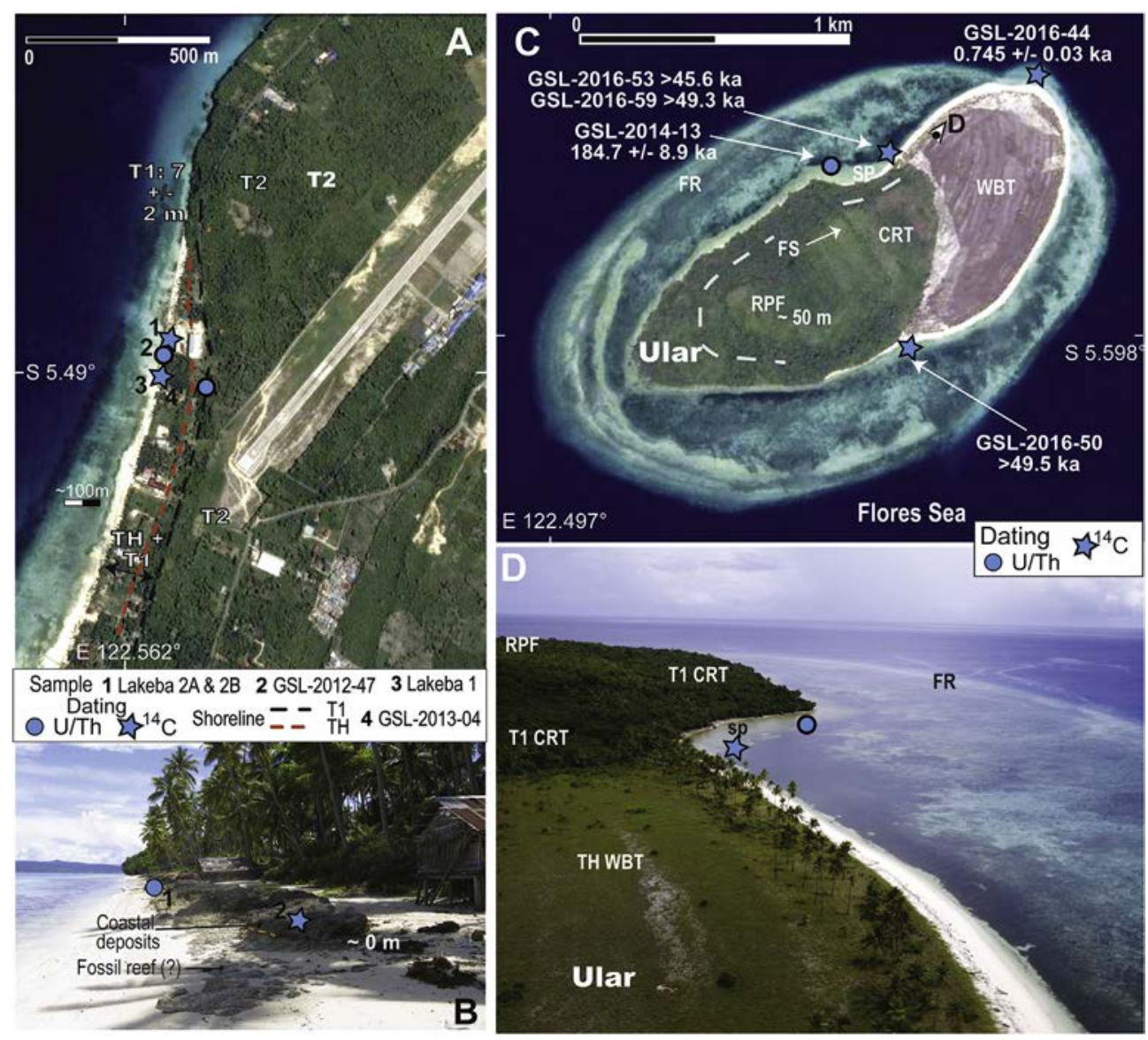

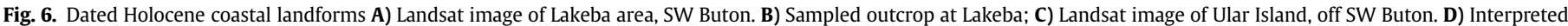

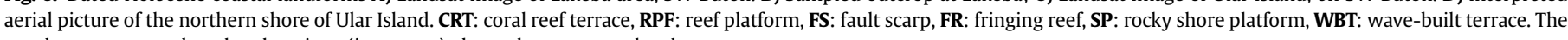
numbers correspond to the elevations (in metres) above the mean sea level.

1986; Pirazzoli, 1994; Pedoja et al., 2014; Murray-Wallace and Woodroffe, 2014) that the geomorphic characteristics of the low landforms (limited widths, reduced karstification, occurrence of soft sediments) are indicative of their young age (Holocene). At each studied site in SE Sulawesi, we therefore postulate that lowlying landforms $(\mathrm{TH}<5 \mathrm{~m})$ relate to the mid-Holocene high-stand ( 9-3 ka), while the rest of the sequence is Pleistocene or older in age.

\subsection{Wangi-Wangi}

Wangi-Wangi, to the North of the Tukang Besi Archipelago (Figs. 1C and 7), has a 50-km-long coastal stretch for a total area of $\sim 200 \mathrm{~km}^{2}$ (Fig. 7B). On the island, the distribution of coral reef terraces (Fig. 7B, C, D) reveals the uplift and coalescence of two main reef platforms. The largest reef platform, that we named Tindoi (Fig. 7B) is 12-km-long, up to $3.5-\mathrm{km}$-wide and trends NW$\mathrm{SE}$. In the central part of the platform, there is a reduced reefal limestone hill at $240 \pm 10 \mathrm{~m}$. The second fossil reef platform, that we named Numana (Fig. 7B), is smaller, 4-km long and up to 3-kmwide, more circular in shape (Fig. 7B) and reaches a maximum elevation of $60 \pm 10 \mathrm{~m}$. The sequence around the Tindoi reef platform $(180 \pm 20 \mathrm{~m})$ includes at least five terraces with some distinct shoreline angles at $68 \pm 5 \mathrm{~m}$ and $98 \pm 7 \mathrm{~m}$. The southern fossil reef platform at $60 \pm 10 \mathrm{~m}$ is surrounded by, at least, two terraces (Fig. 7B).

On the NE shore of Wangi-Wangi, the Patuno Resort is built on a narrow wave-built terrace associated to a notch $(1.5 \pm 0.5 \mathrm{~m})$ that we correlate to the Holocene (see 4.2 , Fig. $7 \mathrm{~B}$ and $\mathrm{E}$ ). The $\sim 10 \mathrm{~m}$ high fossil sea cliff exhibits two other notches at elevations of $4 \pm 1 \mathrm{~m}$ and $7 \pm 2 \mathrm{~m}$. Terrace $\mathrm{T} 1$ is $\sim 800 \mathrm{~m}$ wide and its shoreline angle is raised at $17 \pm 2 \mathrm{~m}$ (Fig. 7C). We sampled corals in T1 limestone (Fig. 7C) at the summit $(+4 \mathrm{~m})$ of the double notch off Patuno resort (GSL 2013-50), and at the distal edge ( $11 \mathrm{~m})$ of T1 terrace (GSL 2013-54). Samples GSL 2013-50 and GSL 2013-54 yielded U/Th ages of $133 \pm 4 \mathrm{ka}$ and $131 \pm 4 \mathrm{ka}$ respectively (Table 1 ). We allocate the limestone unit and terrace T1 to the last interglacial maximum (MIS 5e).

\subsection{SW Buton and islands}

The city of Bau Bau (SW Buton) is built on a sequence of coral reef terraces (Fig. 5A). This sequence forms a fossil cape conform to its modern counterpart (Fig. 5B) and when observed from the sea, appears as a gentle anticline whose maximum elevation reaches $\sim 280 \mathrm{~m}$ westward of Lakeba (Fig. 5A). In Bau Bau area, we identified at least 11 successive terraces up to $\sim 180 \mathrm{~m}$. Samples were collected from Lakeba and Nirwana areas, to the South of the city (Fig. 5B).

At Lakeba, we focused on the Holocene strandline (section 4.1, Fig. $6 \mathrm{~A}, \mathrm{~B}$ ). Above the sedimentary TH terrace, there is a reduced T1 terrace (Fig. 6A. To the North of Lakeba, T1 terrace width is $\sim 4-10 \mathrm{~m}$ and its shoreline is raised at $7 \pm 2 \mathrm{~m}$. In the centre of the bay, T1 shoreline is associated to a notch at $8 \pm 1 \mathrm{~m}$ (Fig. 6A). Above T1, there is a wide coral reef terrace, $\mathrm{T} 2$, whose shoreline is present at 


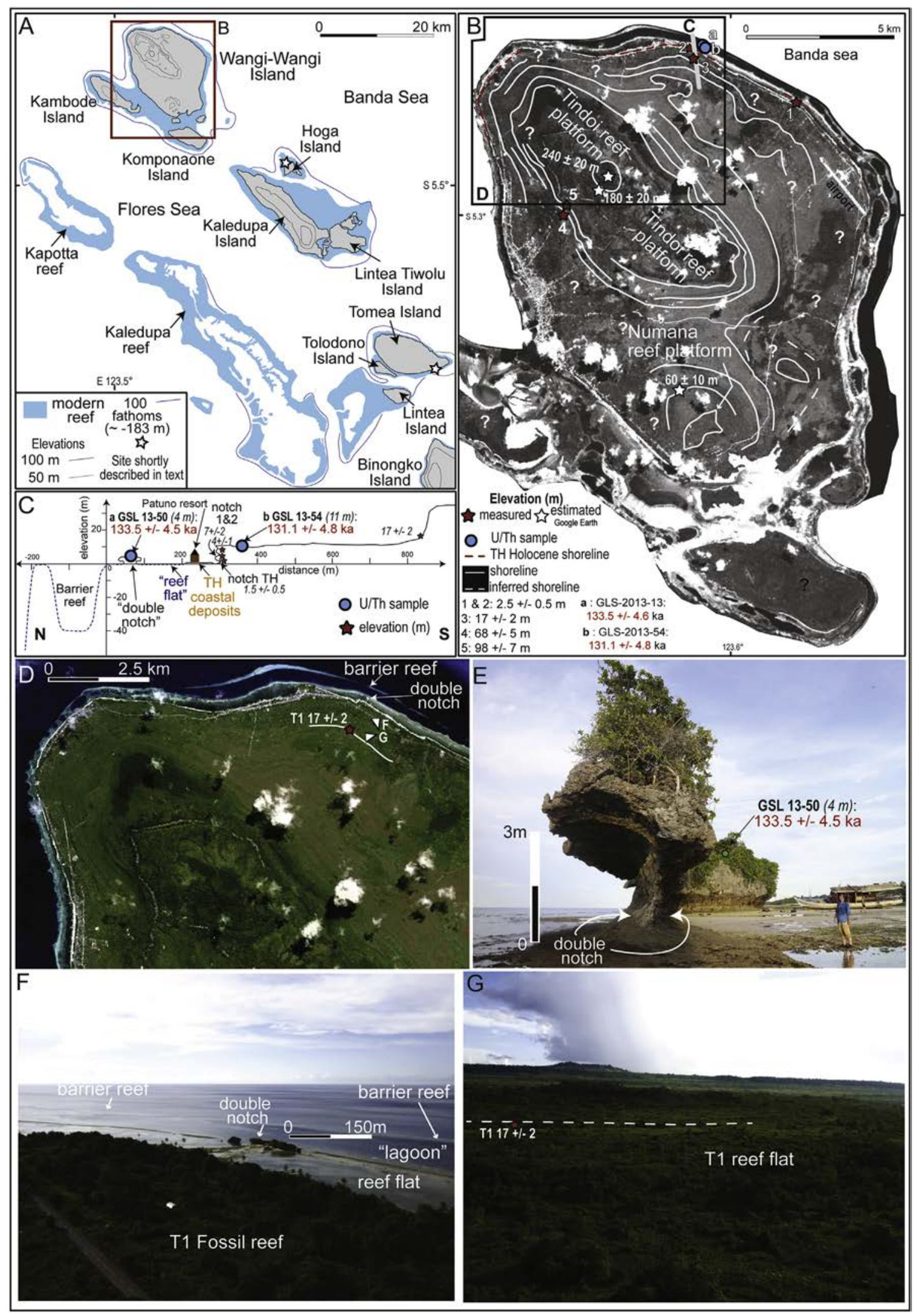

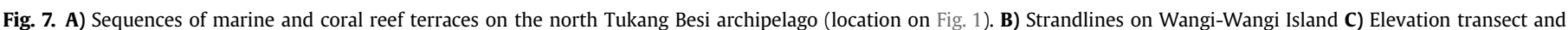

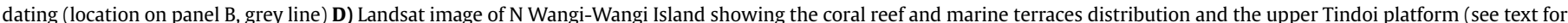

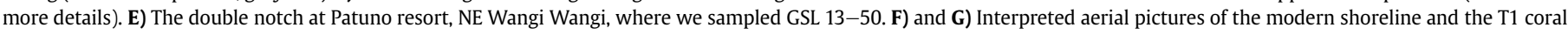
reef terrace next to Patuno resort. 
$33 \pm 2 \mathrm{~m}$ where the city airport stands (Fig. $6 \mathrm{~A}$ ). To the North, T1 is discordant on Sampolakosa Fm. We extracted coral samples in the fossil sea cliff associated to CRT 1 (sample GSL 2013 -04) at an elevation of 18-20 m. Sample GSL 2013-04 yielded a U/Th age of $217.5 \pm 16.1 \mathrm{ka}$ (Table 1 ). We tentatively allocated the upper T2 terrace to MIS 7.

To the south of Nirwana bay, we measured the elevation of eight successive strandlines up to $103 \pm 5 \mathrm{~m}$ (Fig. 5D). We sampled GSL $2012-15$ to the north of the bay at the elevation of T2 ( 20 m), but in an area where the terrace morphology is not obvious due to faulting and urban development. GSL 2012 -15 yielded a U/Th age of $135.3 \pm 3.5 \mathrm{ka}$, which leads us to correlate T2 to MIS 5e high-stand (Table 1).

Kadatua Island is $8 \mathrm{~km}$ long and $4.5 \mathrm{~km}$ wide. It reaches elevations of $\sim 100 \pm 10 \mathrm{~m}$ (Fig. 5B). On its western side, from the sea to one of the widest terraces of the sequence (T4 on Fig. 8A), we identified 3 successive strandlines (Fig. 8A, B, C, D), T1, T2 and T3 up to $35 \pm 4 \mathrm{~m}$. T2 is a compound terrace (T2' and T2" on Fig. $8 \mathrm{C}$ ). We sampled corals from T2" (GSL 2012-13 and duplicate) and T3 (GSL 2013-69 and GSL 2013-70) (Fig. 8B and C). Corals samples drilled in T2" yielded U/Th ages of $189.3 \pm 2.8 \mathrm{ka}$ (GSL 2012-13) and $194.3 \pm 10.9$ ka (GSL 2012-13 and duplicate) (Table 1, Fig. 8C). Samples drilled in T3 yielded U/Th ages of $127.5 \pm 2.8 \mathrm{ka}$ (GSL 201369) and $128.17 \pm 2.7 \mathrm{ka}$ (GSL 2013-70) (Table 1, Fig. 8C). The straightforward morpho-stratigraphic interpretation would consist in allocating T2" to MIS 7a and the T3 terrace to MIS 5e. We discard this hypothesis because coastal erosion truncates underlying strata. Consequently, we allocate T3 to MIS 5e high-stand and suggest that carving of T2" occurred later (MIS 5c, 5a?), into a reef limestone unit related to MIS 7.

Siumpu Island is $10 \mathrm{~km}$ long and $5 \mathrm{~km}$ wide (Fig. $5 \mathrm{~A}$ and B). As Wangi-Wangi, it is composed of two coalescent uplifted reef platforms bordered by extensive sequences of coral reef terraces (Fig. 5B). The largest reef platform, in the NE of Siumpu, is raised at $\sim 250 \mathrm{~m}$ whereas the smallest one is raised at $\sim 80 \mathrm{~m}$ (Fig. 5B). In NE Siumpu, the sequence includes a minimum of 15 successive strandlines. We studied its lower part and recognized nine successive terraces, up to $\sim 160 \mathrm{~m}$ (Fig. 8E, F, G). The shoreline angle of T3 was measured at $54 \pm 1 \mathrm{~m}$ (Fig. 8G). GSL 2012-33 was sampled in the limestone constituting the distal edge of the terrace (Fig. $8 \mathrm{~F}$ and $\mathrm{G}$ ) and yielded a U/Th age of $245.6 \pm 13.1$ that we correlate to MIS 7e (Table 1).

\subsection{SE Buton}

West of the Sampolawa fault (Fortuin et al., 1990), SE Buton Island consists in a $\sim 12 \times 7 \mathrm{~km}$, fossil reef platform, heavily karstified and bordered by extensive sequences of marine and coral reef terraces to the north and south (Figs. 9-12). On its SE side, the fossil reef platform does not display any terrace (Fig. 10A). In the Gulf of Pasarwajo, we identified a minimum of 40 successive terraces on satellite images (Fig. 10B) reaching a maximum elevation of $650 \pm 10 \mathrm{~m}$ to the NE (Fig. 10A and B). Field data and SRTM satellite images and DEM (Fig. 10C-F) reveal that the terraces are clearly tilted, warped and faulted. Their large-scale deformation outlines the underlying anticline (Fig. 10A, E). In the Gerak Makmur area, at least 30 successive terraces up to $550 \pm 10 \mathrm{~m}$ in elevation circumscribe two embayments that coalesced to form the modern Nalandi

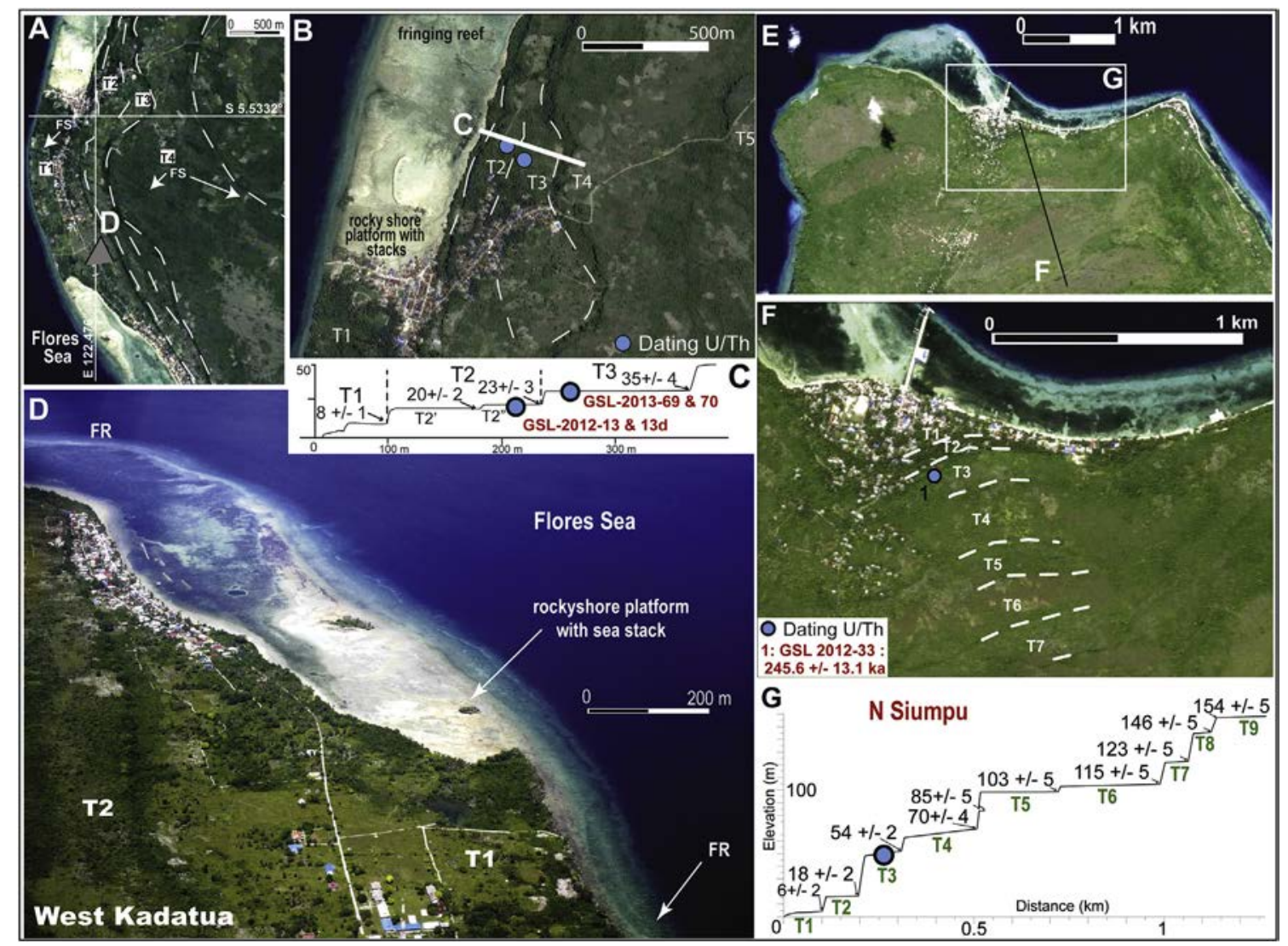

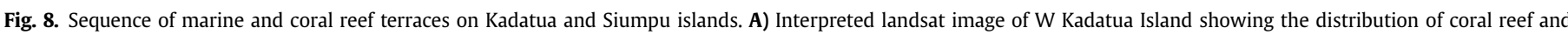

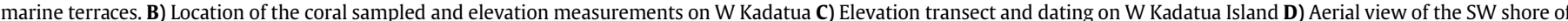

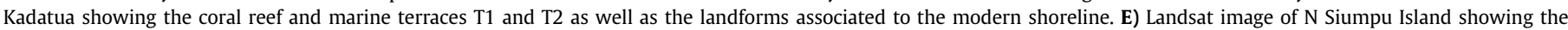

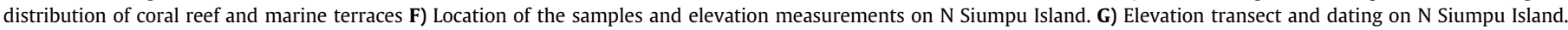




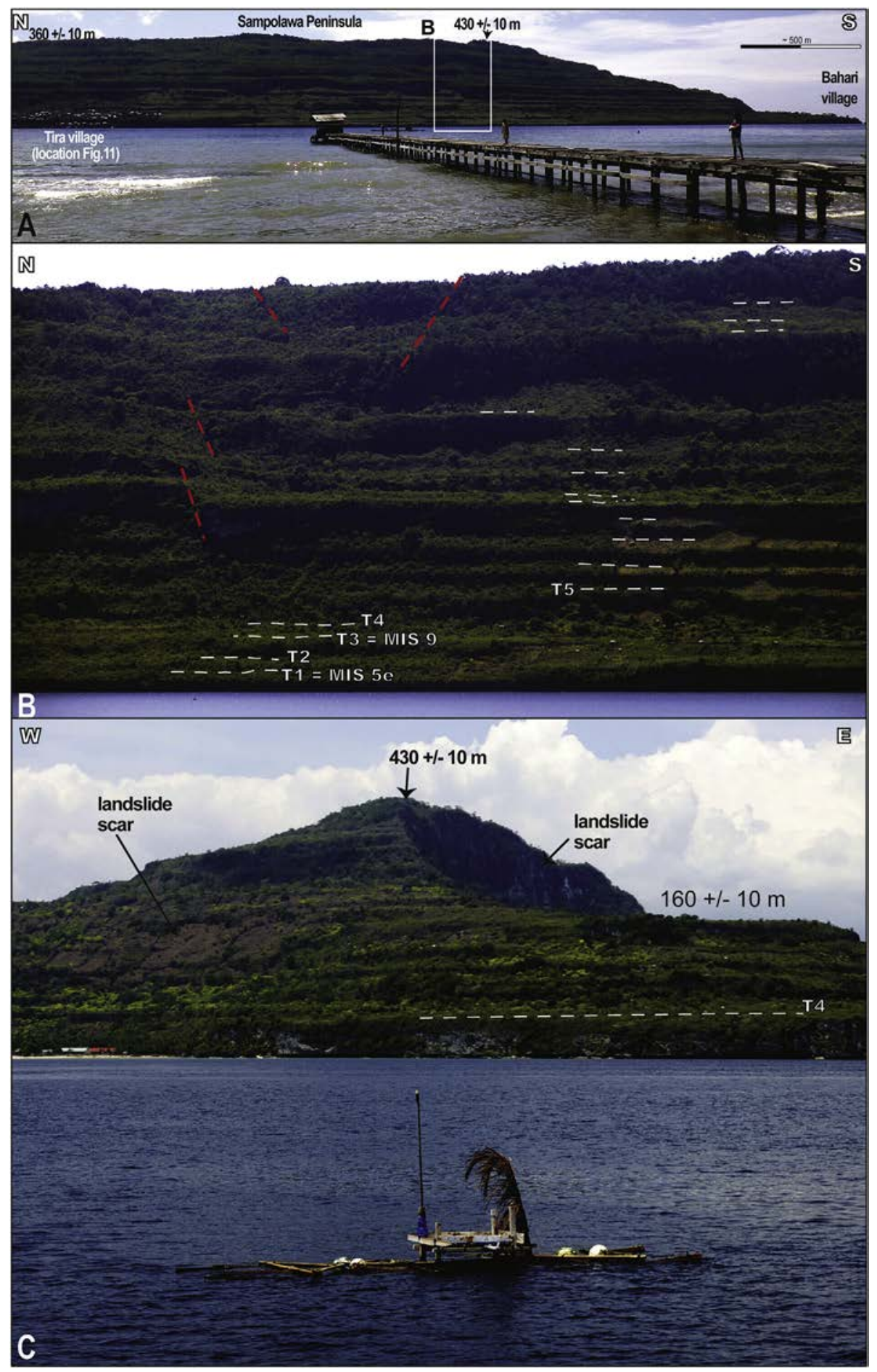

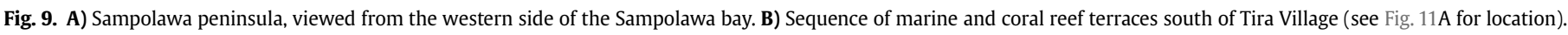

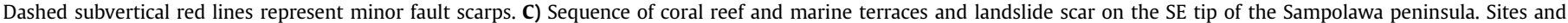
orientation of the pictures on Fig. 5A. (For interpretation of the references to colour in this figure legend, the reader is referred to the Web version of this article.)

bay (Fig. 10A). At Laboke point, NE-SW trending faults delimit the distribution of the staircase sequence that reach $\sim 180 \mathrm{~m}$ and includes at least 13 terraces. At all sites, within the reef limestone of the low standing terraces, the lack of pristine coral samples precluded $\mathrm{U} / \mathrm{Th}$ dating.

The $6 \mathrm{~km}$-long and $2-3 \mathrm{~km}$-wide Sampolawa Peninsula is delimited by the Nalandi Bay (E) and the Sampolawa Fault (W) (Fig. 10A). It exhibits a notable sequence of fossil reefs (see
Figures in Verbeek, 1908; Fortuin et al., 1990; Pedoja et al., 2011), that culminates at $430 \pm 10 \mathrm{~m}$ and includes a minimum of 18 successive strandlines (terraces, notches). On its SE side, the peninsula is indented by large landslides (Figs. 9-11). Between Bahari and the south of Tira (Fig. 11A and B), the shoreline angles of the terraces and the notches are horizontal and laterally continuous over $\sim 2 \mathrm{~km}$ (Fig. 11A and B), even if they sometimes display lateral geomorphic changes from fringing reefs to notches, for example. South of Tira 


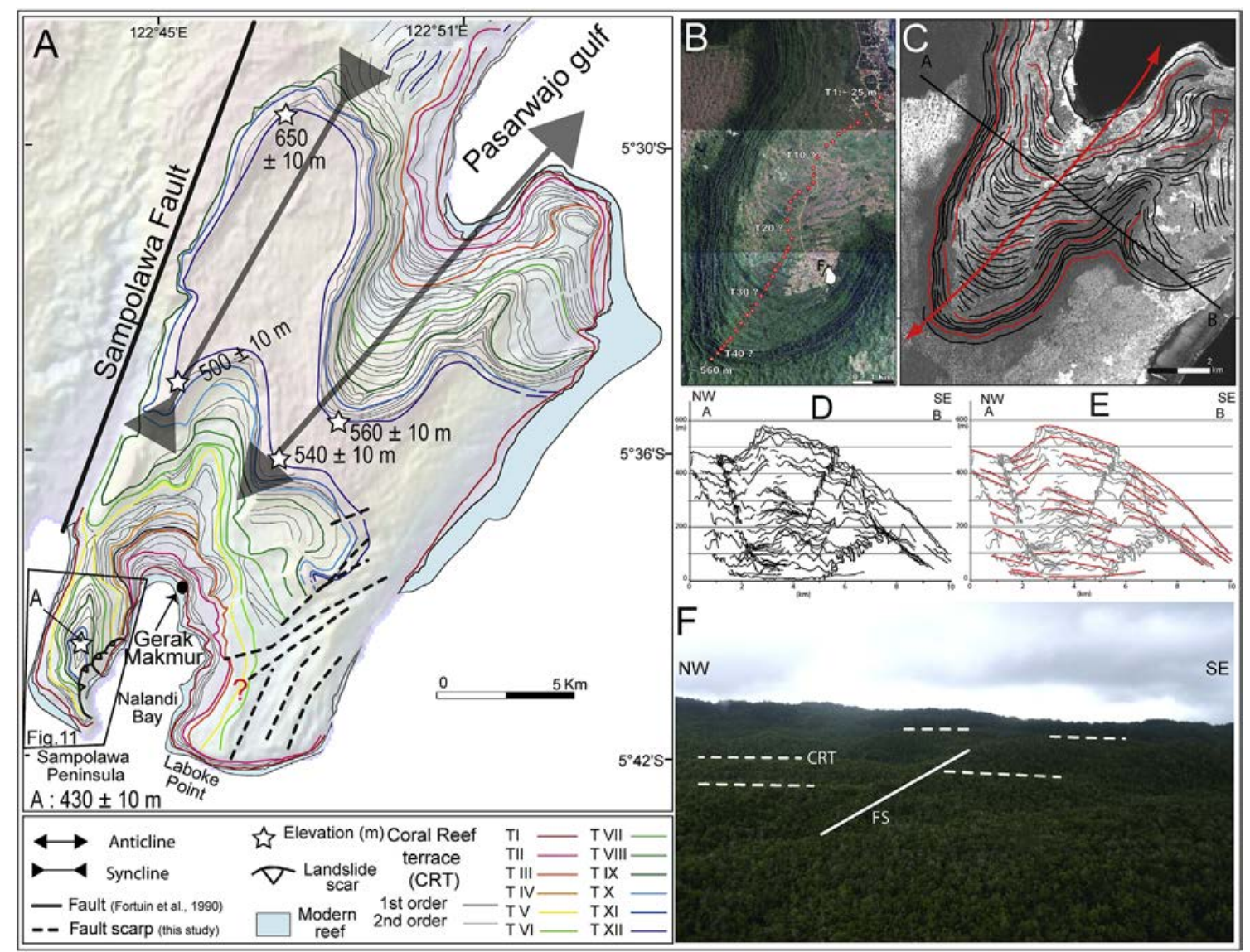

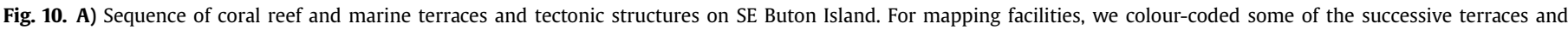

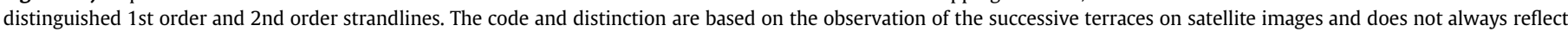

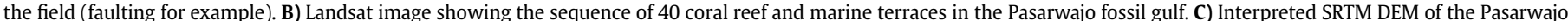

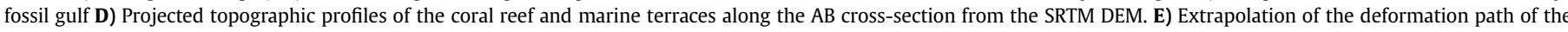

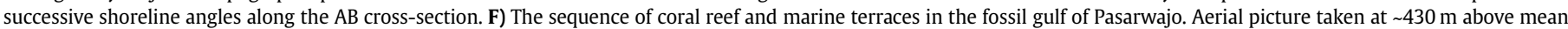

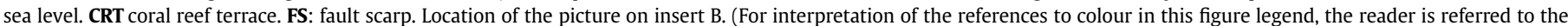
Web version of this article.)

village, a system of NE trending vertical faults increasingly offsets the terraces from a $1-2 \mathrm{~m}$ at low elevations (T1 and T2) to $15 \pm 5 \mathrm{~m}$ for T10 (supplementary data, flight Tira south).

South of the NE trending faults, the lower part of the sequence includes four well-preserved coral reef terraces reaching, for T4's shoreline an elevation of $51 \pm 5 \mathrm{~m}$ (Figs. 11B and 12). The slopes of the three lowermost terraces (T1 to T3) vary between the inner (shallow-dipping) and the outer part of the terrace (steeper-dipping). By comparison with the modern shore that we surveyed by boat and snorkelled, we interpret such variation in slope as the joint occurrence of a steeper fossil reef and of a shallow-dipping rocky shore platform carved in the limestone of T1 (see section 3.1). Sample GSL 2013-16 was drilled at $19-20 \mathrm{~m}$ next to T2 's shoreline angle (at $22 \pm 3 \mathrm{~m}$ ). The coral sample yielded a $U /$ Th age of $304 \pm 28 \mathrm{ka}$ (Fig. 12A, Table 1). Within the large margin of error of our dating, we correlate the reef limestone dated to the nearest, MIS $9(324.5 \pm 18.5 \mathrm{ka})$ high-stand. Our observations suggest that the inner edge of T2 is a rocky-shore platform carved in the reef limestone of T3. Consequently, we allocated the above terrace (T3) to MIS 9.

At the southern tip of the Sampolawa Peninsula, we carried out two dGPS elevation transects (Fig. 11 B, D and E) up to elevations of $430 \pm 10 \mathrm{~m}$. Many terraces are morphologically continuous between both transects (in bold on Fig. 11D and E). To the sides of the Bahari embayment, the Holocene to modern notch reaches elevations of $2.5 \pm 0.5 \mathrm{~m}$ (see 4.2). In the middle of the bay, conversely, wave-built deposits (TH) are found up to $\sim 5 \mathrm{~m}$. In this area, $\mathrm{TH}$ and $\mathrm{T} 1$ are compound terraces probably because of reworking, and have merged into a single landform that culminates at $15 \pm 2 \mathrm{~m}$ (Fig. 11D and $\mathrm{E}$ ). To the centre-east of the Bahari embayment, we collected GSL 2012-36 within T1 limestone at $12-13 \mathrm{~m}$, the shoreline of the terrace being at $15 \pm 2 \mathrm{~m}$ (Table 1 , Fig. 11B). GSL 2012-36 yielded an age of $112 \pm 4.1 \mathrm{ka}$ (Table 1 ) which leads us to allocate T1 to MIS 5e high-stand. We correlate T3 to MIS 9 , because of the lateral continuity of the terrace toward the neighbouring dated site of southern Tira (Sample GSL 2013-16).

\section{Discussion}

\subsection{Palaeogeographical evolution of SE Sulawesi or the elevated reef-limestone-island factory}

The distribution and morphology of reefs and islands in SE Sulawesi reveal a palaeogeographic evolution that corresponds to the uplift and occasional coalescence of elevated reef limestone islands. A synthetic geomorphic scenario is proposed, based on the morphology of the islands from the Tukang Besi and Buton archipelagos (Fig. 13). The initial stage (Fig. 13A1-B1) is that of a reef platform or a table reef whose size typically ranges from a few tens of metres to tens of kilometres with various shapes: e.g., the Kapota 


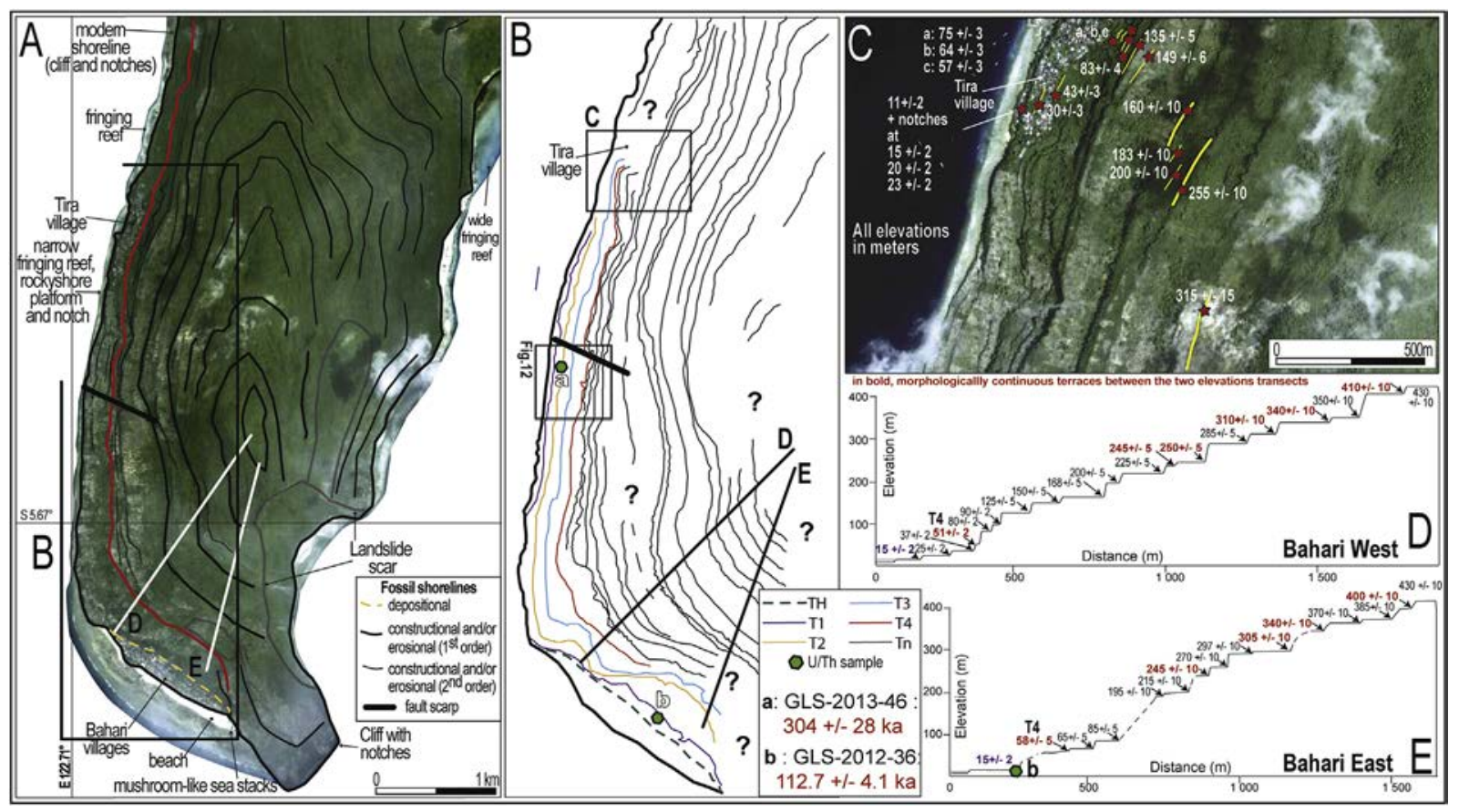

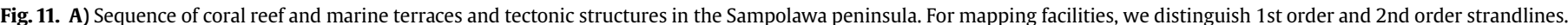

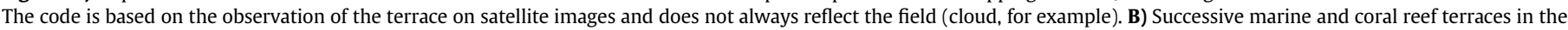

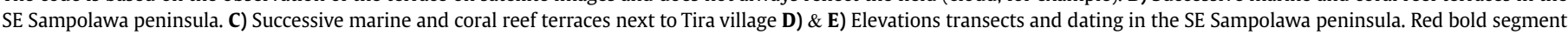

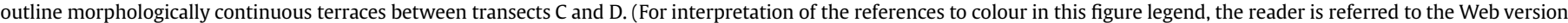
of this article.)

and Kaledupa reefs are large, oblong reef platforms (Fig. 7A) whereas the Koro Maha reef is more circular (Fig. 13C stage 0 ). The first stage consists in the uplift of a flat, low-lying coral reef island bordered by a fringing coral reef (Fig. 13A2, B2). Hoga Island is flat, $\sim 3.5 \mathrm{~km}$ long and $2.5 \mathrm{~km}$ wide, low-lying $(<20 \mathrm{~m})$ and totally surrounded by a typically $1-\mathrm{km}$-wide fringing reef. To the East of Hoga Island, the modern shoreline is marked by a $1-1.5 \mathrm{~m}$ sea cliff associated with a narrow notch carved in the limestone of an emerged coral reef (Fig. 13 stage 1). The surface of the karstified fossil reef is at $\sim 4 \mathrm{~m}$ in elevation (Fig. 13C stage 1 ). To the North of the island, limestones are found up to $\sim 20 \mathrm{~m}$ in elevation but no clear staircase morphology (terrace) is observed. Emerging islands further expand by the formation of successive coral reef terraces that form during separate sea-level high-stands leading to one, two (stage 2 on Fig. 13) or more stages (stage n on Fig. 13). Eventually, uplifting reef platforms and/or table reefs may coalesce such as on Binongko, Wangi-Wangi or Siumpu (Fig. 13C stage 2). Tomea and Binongko islands (Figs. 1 and 7) or the SE corner of Buton Island consist in stage $\mathrm{n}$ elevated island (Fig. 13B). For example, Tomea includes at least 14 successive strandlines (Tjia et al., 1974). On SE Tomea, at the western tip of a $\sim 1 \mathrm{~km}$ long embayment, we observed a sequence of three notches above the modern one in a 25-m-high sea cliff. We measured the elevation of the notches with the telemetry system tied to the quadcopter as well as by direct measurement by aiming a distance-meter at the flying quadcopter. The notches are found at $4 \pm 0.5 \mathrm{~m}, 9 \pm 1 \mathrm{~m}$ and $17 \pm 3 \mathrm{~m}$. For a photogrammetric model of the cliff, please see https://goo.gl/ULXY7Q).

Overall, the late Cenozoic progressive uplift of submarine banks and shoals first led to the formation of platforms and table reefs on top of morphological highs. Tectonic uplift subsequently allowed the development of sequences of fringing coral reef terraces to form $\sim 30$ elevated reef limestone islands (Fig. 1C). In SE Sulawesi, the slow to moderate, long lasting uplift (see sections 5.2,5.3) resulted in highly elevated sequences, especially on S Buton (see Fig. 5) which could, in theory (Montaggioni and Braithwaite, 2009) include terraces correlated to low-stands (Fig. 13 A3-4).

\subsection{Estimates of Middle and Upper Pleistocene uplift rates}

We derive both apparent and eustasy-corrected uplift rates from shoreline angle elevations of dated terraces (Table 3). Within the study area, we identified, at elevations lower than $60 \mathrm{~m}$, terraces allocated to the three last interglacial periods (MIS 5e, 7, 9). At four sites, we allocated a terrace or a reef limestone unit to MIS 5e, at four sites to MIS 7 and at one site to MIS 9 (Table 1, for a probability density plot following the interglacial stages and sub-stages see Fig. 14A).

On NE Wangi-Wangi, MIS 5e apparent uplift rates are of $0.14 \pm 0.02 \mathrm{~mm} \mathrm{yr}^{-1}$ and eustasy-corrected uplift rates have a mean of $0.13 \pm 0.11 \mathrm{~mm} \mathrm{yr}^{-1}$ (Table 3, Fig. 14B). On W Kadatua, apparent MIS 5e uplift rates are of $0.29 \pm 0.05 \mathrm{~mm} \mathrm{yr}^{-1}$ and eustasycorrected uplift rates have a mean of $0.28 \pm 0.13 \mathrm{~mm} \mathrm{yr}^{-1}$ (Table 3 , Fig. 14B). In $\mathrm{N}$ Siumpu, apparent MIS 7 uplift rates are of $0.25 \pm 0.04 \mathrm{~mm} \mathrm{yr}^{-1}$ and eustasy-corrected uplift rates have a mean of $0.32 \pm 0.12 \mathrm{~mm} \mathrm{yr}^{-1}$. Finally on the SE Sampolawa Peninsula, both apparent MIS 5e and MIS 9 uplift rates are of $0.12 \pm 0.02 \mathrm{~mm} \mathrm{yr}^{-1}$ (Table 3, Fig. 14B). Mean eustasy-corrected uplift rates since MIS $5 \mathrm{e}$ are $0.11 \pm 0.11 \mathrm{~mm} \mathrm{yr}^{-1}$ whereas MIS 9 uplift rates mean to $0.14 \pm 0.09 \mathrm{~mm} \mathrm{yr}^{-1}$ (Table 3, Fig. 14B).

Average apparent or eustasy-corrected uplift rates are around $0.1-0.3 \mathrm{~mm} \mathrm{yr}^{-1}$, which correspond to low to moderate rates (Classes C and B as in Pedoja et al., 2011). In SE Sulawesi, uplift rates vary in space and time as evidenced locally, for example, by the faulting and folding of the upper terraces within the Pasarwajo Gulf (Fig. 10 C, D, E). At a regional scale, at this stage of study, MIS 5e uplift rates are higher on the Kolodonale block to the NW (W Kadatua, apparent uplift rate of $0.29 \pm 0.05 \mathrm{~mm} \mathrm{yr}^{-1}$ ) than on the Lucipara block to the SE (Wangi-Wangi apparent uplift rate of 


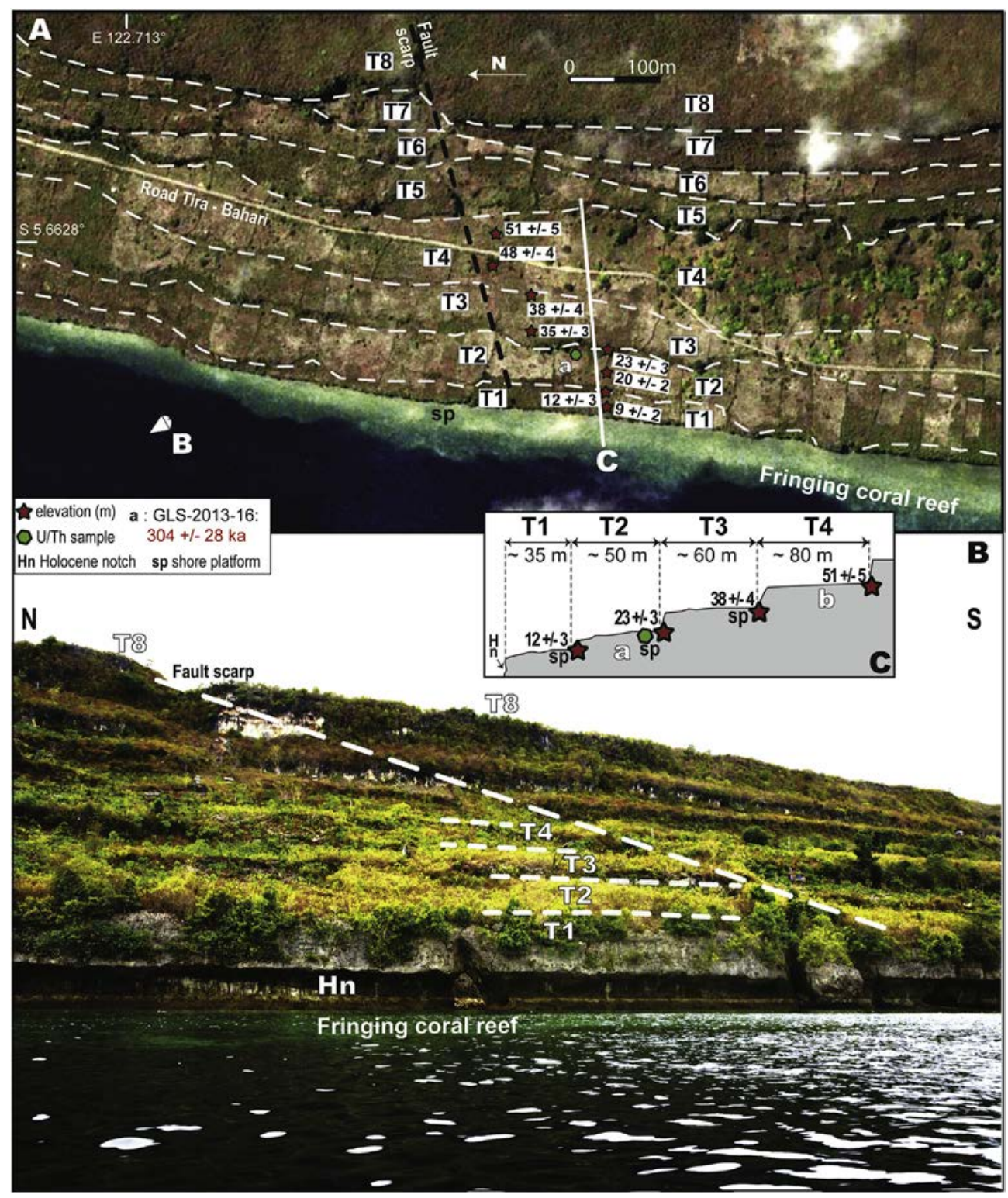

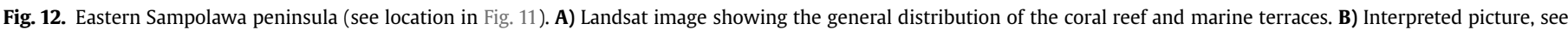
location on panel A. C) Elevation transect and dating.

$\left.0.14 \pm 0.02 \mathrm{~mm} \mathrm{yr}^{-1}\right)$. At a larger scale, we suggest that there is a northward decrease of coastal deformation intensity in eastern Indonesia (section 2.2 and Fig. 2).

\subsection{Timing for the onset of some sequences from SE Sulawesi}

Assuming constant uplift rates, we extrapolate the mean eustasy-corrected uplift rates to propose a possible age for the uppermost shorelines of the sequences (as in Lajoie, 1986). These extrapolations provide an indicative chronological framework that we discuss with regard to the regional geology.

Extrapolating a mean eustasy-corrected uplift rate of $0.13 \pm 0.11 \mathrm{~mm} \mathrm{yr}^{-1}$ the summit of Wangi-Wangi $(240 \pm 10 \mathrm{~m})$ emerged between $12.5 \mathrm{Ma}$ and $1 \mathrm{Ma}$ with a mean of $1.9 \mathrm{Ma}$. The Tindoi fossil reef platform $(\sim 180+/ 20 \mathrm{~m})$ emerged between $10 \mathrm{Ma}$ and 0.6 Ma with a mean at 1.4 Ma. Finally, the Numana fossil reef platform $(\sim 60 \pm 10 \mathrm{~m})$ emerged between 3.5 Ma and 0.2 Ma (mean at $0.5 \mathrm{Ma})$. Siumpu Island $(250 \pm 10 \mathrm{~m})$ presents a local mean eustasy-corrected MIS 7e uplift rate of $0.32 \pm 0.12 \mathrm{~mm} \mathrm{yr}^{-1}$ which suggest emersion between 1.3 and $0.5 \mathrm{Ma}$ (mean at $0.8 \mathrm{Ma}$ ). On Kadatua $(\sim 100 \pm 10 \mathrm{~m})$ the mean MIS 5e eustasy-corrected uplift rate of $0.28 \pm 0.13 \mathrm{~mm} \mathrm{yr}^{-1}$ suggests that the island could have emerged between $0.7 \mathrm{Ma}$ and $0.2 \mathrm{Ma}$ (mean at $0.4 \mathrm{Ma}$ ).

For the Sampolawa Peninsula $(430 \pm 10 \mathrm{~m})$, in SE Buton, we extrapolated a mean eustasy-corrected MIS 9 uplift rate of $0.13 \pm 0.06 \mathrm{~mm} \mathrm{yr}^{-1}$ (uplift 1) and an uplift rate of $0.11 \pm 0.02 \mathrm{~mm} \mathrm{yr}^{-1}$ (uplift 2) obtained according to the values of Murray-Wallace and Woodroffe (2014). According to those uplift rates the onset of the $430 \mathrm{~m}$ high sequence on the Sampolawa Peninsula occurred between 2.2 Ma and 6.2 Ma (uplift 1) or 3.2 and 4.8 Ma (uplift 2).

These extrapolations, even with their large margins of error, are compatible with earlier estimates in this area. The Sampolawa sequence of coral reef terraces was proposed to be Plio-Quaternary 


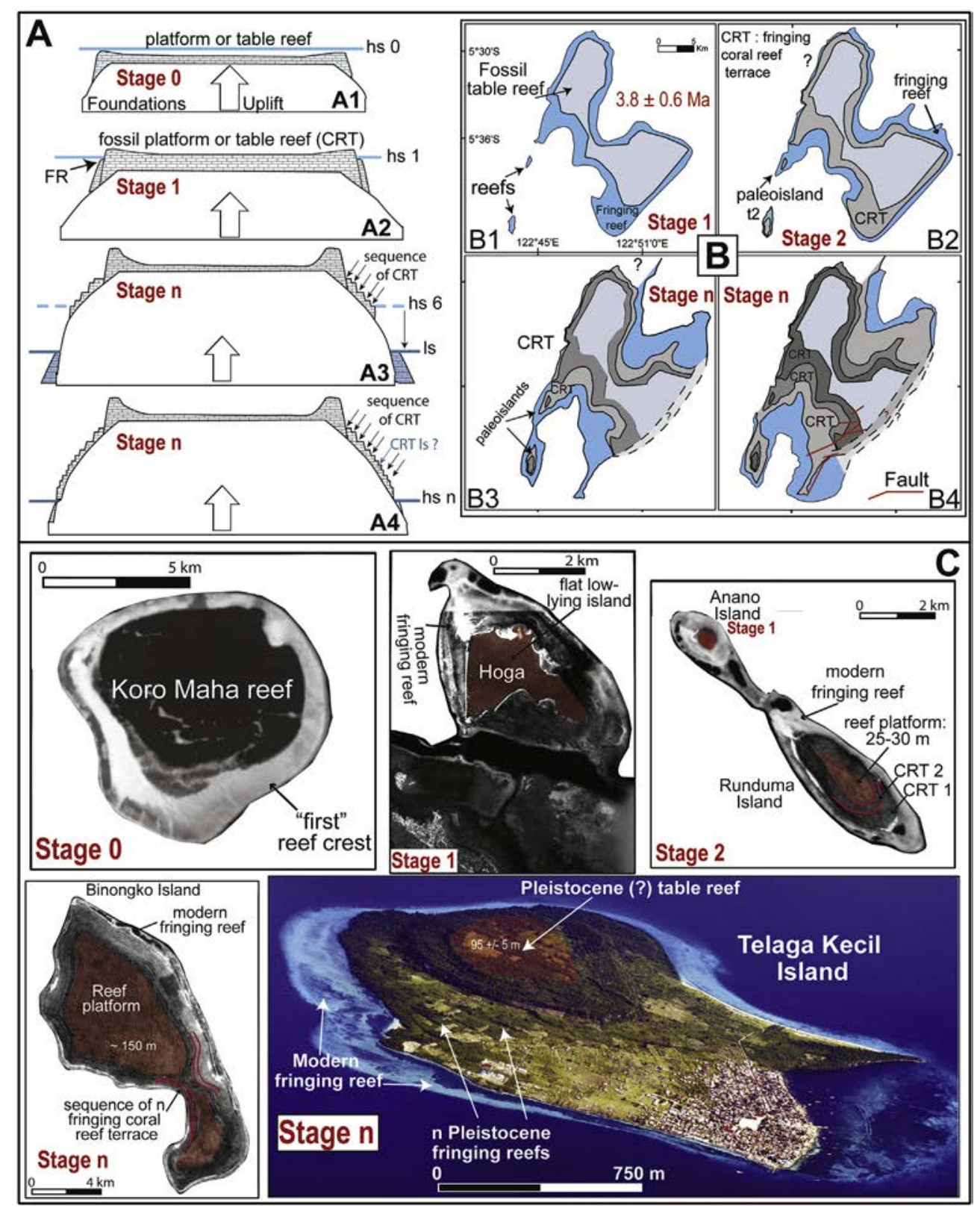

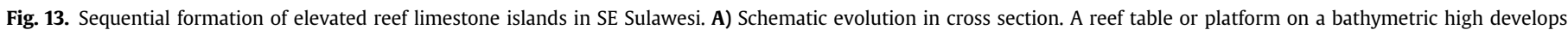

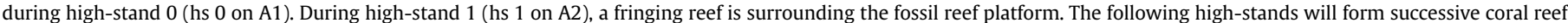

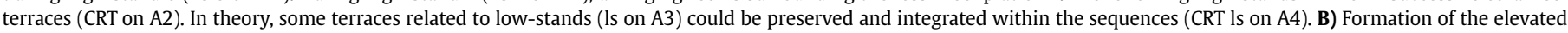

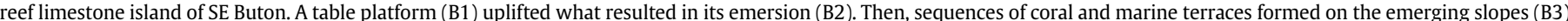

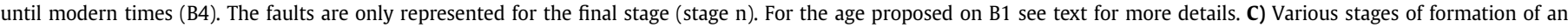
elevated reef island, from stage 0 to stage $\mathrm{n}$ from the Tukang Besi archipelago. Islands location on Fig. 1C. Aerial view of Telega-Kecil Island (location Fig. 1B); stage n.

as early as in the beginning of 20th century (Verbeek, 1908). Chronological constraints on microfossils from the limestones of the terraces (i.e., the Wapulaka Formation see Settings) led previous authors (Fortuin et al., 1990; Satyana and Purwaningsih, 2011) to suggest that the sequence is bracketed between the planktonic foraminifera zones N21 (4.4 Ma to $1 \mathrm{Ma}$ ) and N22/23 (from $1 \mathrm{Ma}$ onwards, Gradstein et al., 2012). Consequently, we postulate that the sequences of S Buton cannot be older than $4.4 \mathrm{Ma}$., and thus, we consider that the Sampolawa Peninsula most probably emerged between 4.4 and $3.2 \mathrm{Ma}(\sim 3.8 \pm 0.6 \mathrm{Ma})$. We stress out here that the sequence including more than 40 terraces found up to $650 \mathrm{~m}$, to the North of the Sampolawa Peninsula, next to Pasarwajo, could constitute an even longer record of Plio-Quaternary sea level.

\subsection{Comparison with other long-lasting emerged sequences of fossil coral reefs}

For their abundant shorelines $(>40)$, the sequences from SE Buton only compare to the sequence of Chala Bay (Peru), which includes 27 successive erosional and depositional shorelines (Goy et al., 1992). Excluding sequences of depositional strandlines (beach-ridges sequence), at a global scale, only 58 described sequences include more than 10 successive marine terraces (Pedoja et al., 2014). Sequences including numerous terraces are found in various geodynamical settings. Their formation is not related directly to uplift rates: they are present in subsiding areas (Hawaii Island; Szabo and Moore, 1986; Ludwig et al., 1991; Webster et al., 


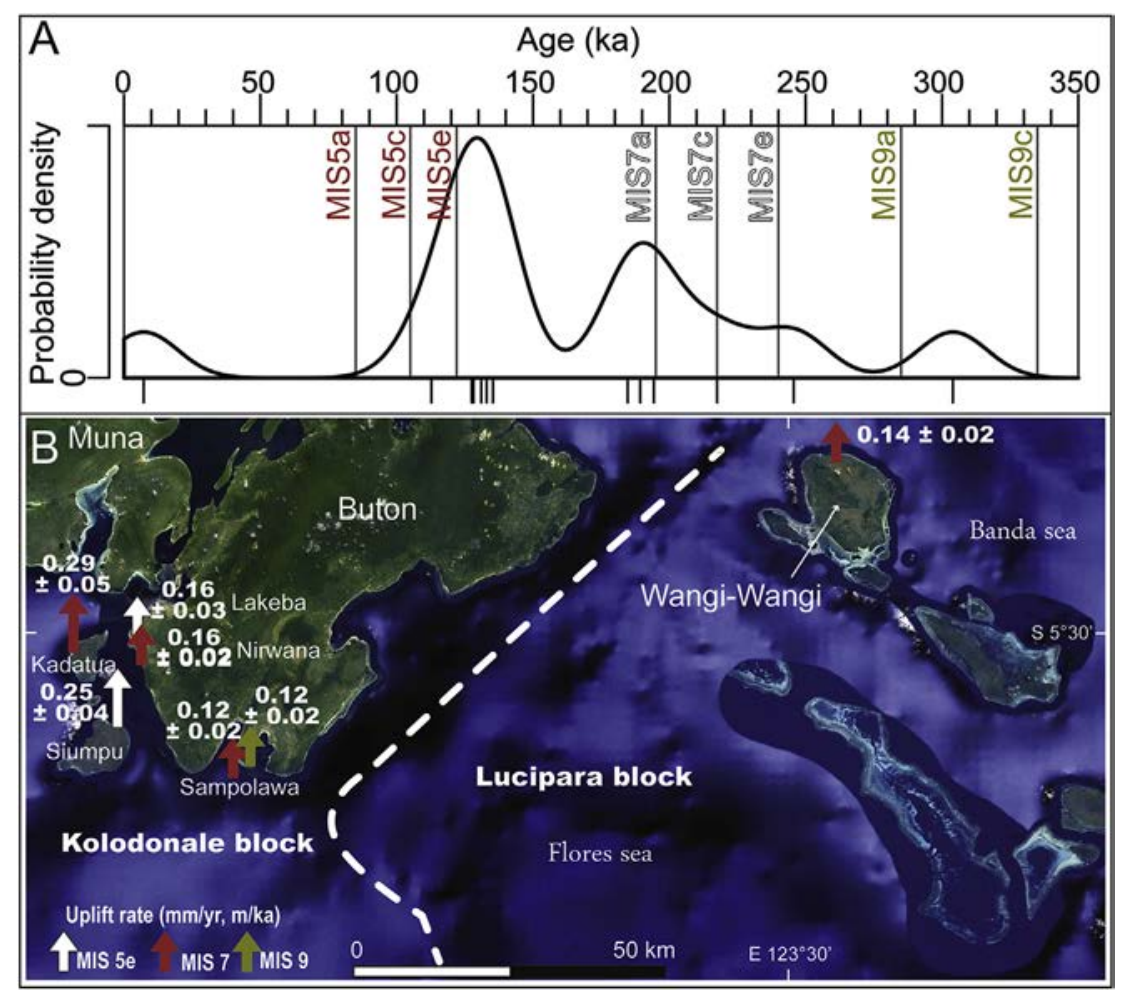

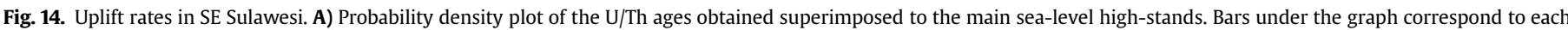
individual sample age. B) Map view of the coastal uplift of SE Sulawesi. MIS 5e: $122 \pm 6$ ka, MIS 7: $217.5 \pm 27.5$ ka, MIS 9: $324.5 \pm 18.5$ ka.

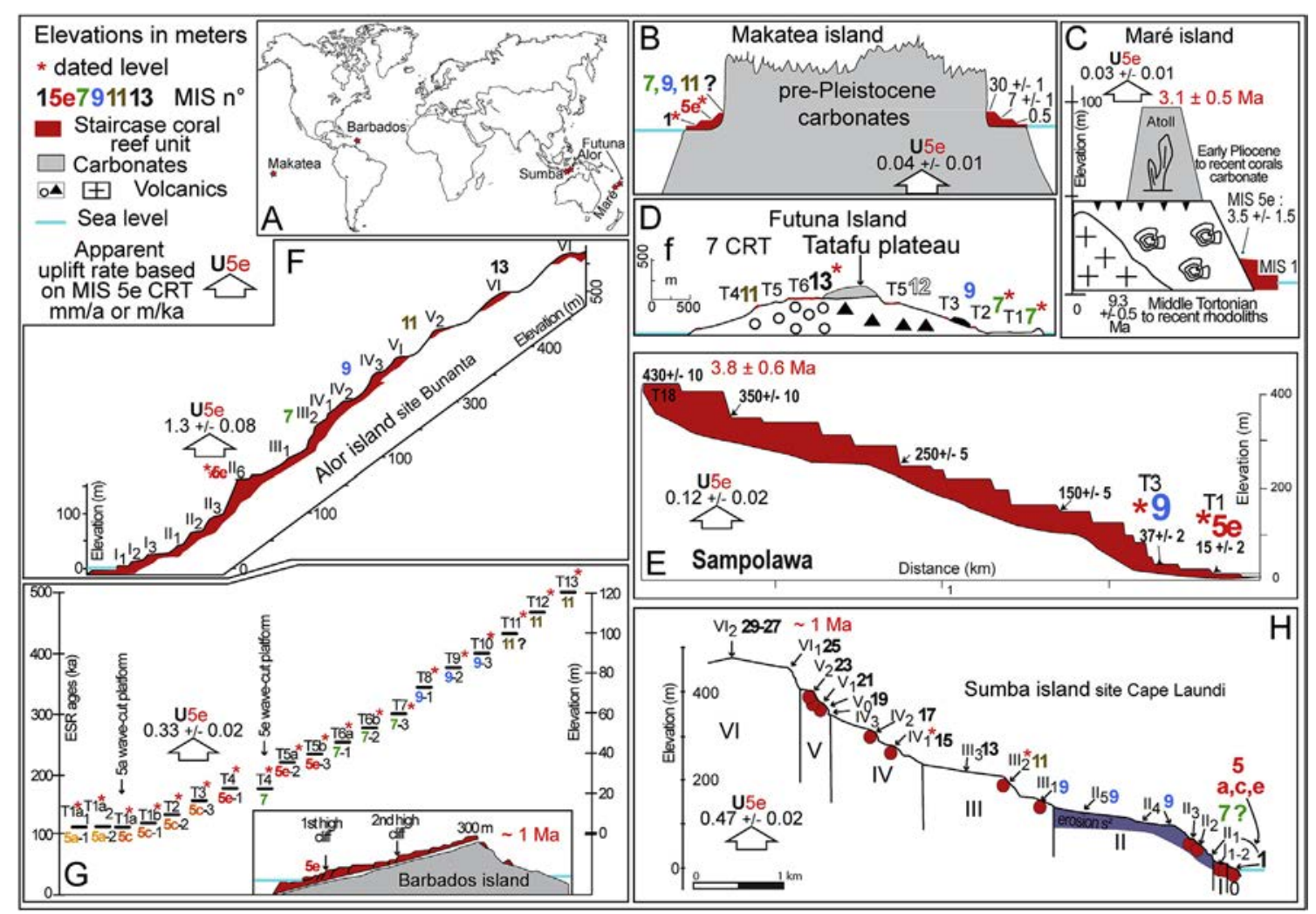

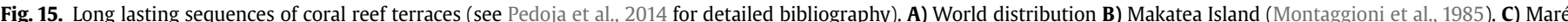

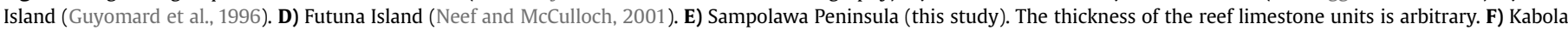

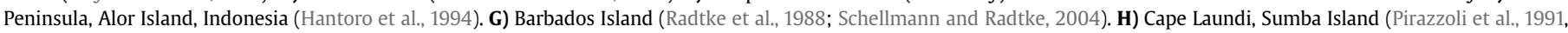
1993). 
2009; Puga-Bernabéu et al., 2016) or on fast uplifting coasts (Huon Peninsula, Papua New Guinea; Bloom et al., 1974; Chappell, 1974).

Long-lasting Late Cenozoic sequences of elevated reefs represent valuable sea level records through the construction of successive limestone units. Such sequences are described within the Caribbean (Haiti, Cuba, Barbados) and Indo-Pacific province (Ryukyu, Makatea, Austral, Cook, Sumba or Alor) (Pedoja et al., 2014, Fig. 15). The coastal sequences from SE Sulawesi constitute an intermediary step between the relatively young (1 Ma on Sumba or Barbados), including numerous successive terraces (18 at Cape Laundi, Sumba), emerged sequences from Sumba, Alor or Barbados and the older and more degraded record of Mahé, Futuna, or Makatea. At the latter sites, only 1 to 6 terraces are present below the limestone constituting the upper table reef or atoll generally composed of early Pleistocene or older fossil reefs (Fig. 15). This intermediary step represents one of the most comprehensive records of sea level high-stands for the Quaternary and possibly part of Pliocene times.

\section{Conclusions}

The Late Cenozoic evolution of SE Sulawesi corresponds to the uplift of a rough sea floor that resulted in the formation of spectacular coastal sequences present on 23 islands. Based on $13 \mathrm{U} / \mathrm{Th}$ and $7{ }^{14} \mathrm{C}$ ages, we allocated coral terrace (or reef limestone unit) to the last interglacial periods (MIS 1, 5e, 7, and 9a). MIS 5e terraces $(122 \pm 6 \mathrm{ka})$ are found at elevations lower than $20 \mathrm{~m}$, except on Kadatua $(34 \pm 5 \mathrm{~m})$. On SE Buton, an undated sequence includes more than 40 successive terraces and reaches $650 \mathrm{~m}$ in elevation. On the neighbouring Sampolawa Peninsula, 18 successive terraces culminate at $430 \pm 10 \mathrm{~m}$ and include MIS 5e and 9 terraces at elevations below $40 \mathrm{~m}$. Extrapolation of eustasy-corrected Middle Pleistocene low uplift rates $\left(0.14 \pm 0.09 \mathrm{~mm} \mathrm{yr}^{-1}\right)$ combined with constraints from local geology suggest that the onset of the sequence on Sampolawa Peninsula started at $3.8 \pm 0.6$ Ma. These sequences therefore correspond to the longest and most comprehensive records of Plio-Quaternary sea level high-stands to date.

\section{Acknowledgments}

We thank Johan Andersen for his constant help, assistance and logistics in the field, as well as many coastal dwellers from the Tukang Besi and Buton archipelago for sharing with us their knowledge of their field. We are grateful to Bert Hoeksema for the identification of fossil corals. We thank ANR program GiSeLE, INSU programs Sulamer Hoplé and Artemis (J-P Dumoulin at LMC14 laboratory) for funding. Many thanks to Nathaniel Findling for the $\mathrm{X}$-ray analysis. SPOT images, used for mapping, were made available by the ISIS program (CNES, distribution SPOT images S.A.). Finally, we thanks 2 editors, 5 anonymous reviewer and A. Puga Bernabéu for fruitful discussions on former versions of this manuscript.

\section{References}

Ali, J.R., Milsom, J., Finch, E.M., Mubroto, B., 1996. SE Sundaland accretion: palaeomagnetic evidence of large Plio-Pleistocene thin-skin rotations in Buton Geological Soc. Lond. Spec. Publ. 106 (1), 431-443.

Andersen, M.B., Stirling, C.H., Potter, E.-K., Halliday, A.N., Blake, S.G. McCulloch, M.T., Ayling, B.F., O'Leary, M., 2008. High-precision U-series measurements of more than 500,000 year old fossil corals. Earth Planet Sci. Lett.
$265(1-2), 229-245$.

Authemayou, C., Pedoja, K., Heddar, A., Molliex, S., Boudiaf, A., Ghaleb, B., Lanoe, B.V.V., Delcaillau, B., Djellit, H., Yelles, K., 2016. Coastal uplift west of Algiers (Algeria): pre-and post-Messinian sequences of marine terraces and rasas and their associated drainage pattern. Int. J. Earth Sci. 1-23.

Berry, L., Whiteman, J., Bell, S.V., 1966. Some radiocarbon dates and their geomorphological significance, emerged reef complex of the Sudan. Z. Geomorphol. 10, 119-143.

Bintanja, R., Van de Wal, R.S.W., 2008. North American ice-sheet dynamics and the onset of 100,000-year glacial cycles. Nature 454 (7206), 869-872.

Springer. In: Bird (Ed.), 2010. Encyclopedia of the World's Coastal Landforms. Springer, Dordrecht Heidelberg London New York.

Blanchon, P., Eisenhauer, A., 2000. Multi-stage reef development on Barbados during the last interglaciation. Quat. Sci. Rev. 20 (10), 1093-1112.

Bloom, A.L., Broecker, W.S., Chappell, J.M.A., Matthews, R.K., Mesolella, K.J., 1974. Quaternary sea level fluctuations on a tectonic coast: New 230Th/234U dates from the Huon Peninsula, New Guinea. Quat. Res. 4 (2), 185-205.

Bowen, D.Q., 2010. Sea level $\sim 400000$ years ago (MIS 11) : analogue for present and future sea-level ? Clim. Past 6, 19-29.

Broecker, W.S., Thurber, D.L., Goddard, J., Ku, T.-l., Matthews, R.K., Mesolella, K.J., 1968. Milankovitch hypothesis supported by precise dating of coral reefs and deep-sea sediments. Science 159 (3812), 297-300.

Cabioch, G., 2011. In: Hopley, D. (Ed.), Emerged Reefs. Encyclopedia of Modern Coral Reefs: Structure, Form and Process. Springer Netherlands, Dordrecht, pp. 373-380.

Caputo, R., 2007. Sea-level curves: perplexities of an end-user in morphotectonic applications. Global Planet. Change 57 (3-4), 417-423.

Chappell, J., 1974. Geology of coral terraces, Huon peninsula, New Guinea; a study of quaternary tectonic movements and sea-Level changes. Geol. Soc. Am. Bull. 85 (4), 553-570.

Chappell, J., Veeh, H.H., 1978. Late quaternary tectonic movements and sea-level changes at Timor and Atauro Island. Geol. Soc. Am. Bull. 89 (3), 356-367.

Chen, J.H., Wasserburg, G.J., von Damm, K.L., Edmond, J.M., 1986. The U-Th-Pb systematics in hot springs on the east pacific rise at $21 \hat{\mathrm{A}}^{\circ} \mathrm{N}$ and guaymas basin. Geochem. Cosmochim. Acta 50 (11), 2467-2479.

Cheng, H., Edwards, R.L., Hoff, J., Gallup, C.D., Richards, D.A., Asmerom, Y., 2000. The half-lives of uranium-234 and thorium-230. Chem. Geol. 169 (1-2), 17-33.

Darwin, C.R., 1842. The Structure and Distribution of Coral Reefs. Being the First Part of the Geology of the Voyage of the Beagle, under the Command of Capt. Fitzroy, R.N. During the Years 1832 to 1836. Smith Elder and Co, London.

Daly, R.A., 1915. The glacial-control theory of coral reefs. In: Proceedings of the American Academy of Arts and Sciences. JSTOR.

Daly, R.A., 1925. Pleistocene changes of level. Am. J. Sci. - Fifth Serie X (58), 281-313.

Dickinson, W.R., 2001. Paleoshoreline record of relative Holocene sea levels on Pacific Island. Earth Sci. Rev. 55, 191-234.

Douville, E., Sallé, E., Frank, N., Eisele, M., Pons-Branchu, E., Ayrault, S., 2010. Rapid and accurate $\mathrm{U}$ - Th dating of ancient carbonates using inductively coupled plasma-quadrupole mass spectrometry. Chem. Geol. 272 (1-4), 1-11.

Dumoulin, J.P., Comby-Zerbino, C., Delqué-Kolic, E., Moreau, C., Caffy, I., Hain, S., Perron, M., Thellier, B., Setti, V., Berthier, B., Beck, L., 2017. Status report on sample preparation protocols developed at the LMC14 laboratory, saclay, France: from sample collection to 14C AMS measurement. Radiocarbon 59 (3), $713-726$.

Dutton, A., Bard, E., Antonioli, F., Esat, T.M., Lambeck, K., McCulloch, M.T., 2009. Phasing and amplitude of sea-level and climate change during the penultimate interglacial. Nat. Geosci. 2 (5), 355-359.

Emiliani, C., 1955. Pleistocene temperatures. J. Geol. 63, 538-578.

Fortuin, A.R., De Smet, M.E.M., Hadiwasastra, S., Van Marle, L.J., Troelstra, S.R. Tjokrosapoetro, S., 1990. Late Cenozoic sedimentary and tectonic history of south Buton, Indonesia. J. Southeast Asian Earth Sci. 4 (2), 107-124.

Goy, J.L., Macharé, J., Ortlieb, L., Zazo, C., 1992. Quaternary shorelines in southern Peru: a record of global sea-level fluctuations and tectonic uplift in Chala Bay. Quat. Int. 15-16, 99-112.

Gradstein, F.M., Ogg, J.G., Schmitz, M.D., Ogg, G.M. (Eds.), 2012. The Geological Time Scale. Amsterdam, Boston, Heidelberg, London, New York, Oxford, Paris, San Diego, San Francisco, Singapore, Sydney, Tokyo. Elsevier.

Grant, K.M., Rohling, E.J., Ramsey, C.B., Cheng, H., Edwards, R.L., Florindo, F., Heslop, D., Marra, F., Roberts, A.P., Tamisiea, M.E., 2014. Sea-level variability over five glacial cycles. Nat. Commun. 5 (5076).

Guilcher, A., 1969. Pleistocene and Holocene sea level changes. Earth Sci. Rev. 5 (2), 69-97.

Guyomard, T.S., Aïssaoui, D.M., McNeill, D.F., 1996. Magnetostratigraphic dating of the uplifted atoll of Maré: geodynamics of the loyalty ridge, SW pacific. J. Geophys. Res. 101 (B1), 601-612.

Hall, R., 2002. Cenozoic geological and plate tectonic evolution of SE Asia and the SW Pacific: computer-based reconstructions, model and animations. J. Asian Earth Sci. 20 (4), 353-431.

Hantoro, W.S., 1992. Etudes des terrasses récifales Quaternaires soulevées entre le détroit de la Sonde et l'île de Timor, Indonésie : Mouvements verticaux de la croûte terrestre et variations du niveau de la mer. Géologie Quaternaire. Aix Marseille, Aix Marseille II: 743pp.

Hantoro, W.S., Pirazzoli, P.A., Jouannic, C., Faure, H., Hoang, C.T., Radtke, U., Causse, C., Borel Best, M., Lafont, R., Bieda, S., Lambeck, K., 1994. Quaternary uplifted coral reef terraces on Alor Island, East Indonesia. Coral Reefs 13 (4), 215-223. 
Hibbert, F.D., Rohling, E.J., Dutton, A., Williams, F.H., Chutcharavan, P.M., Zhao, C., Tamisiea, M.E., 2016. Coral indicators of past sea-level change: a global repository of U-series dated benchmarks. Quat. Sci. Rev. 145 (Suppl. C), 1-56.

Hilgen, F.J., Lourens, L.J., Van Dam, J.A., Beu, A.G., Boyes, A.F., Cooper, R.A., Krijgsman, W., Ogg, J.G., Piller, W.E., Wilson, D.S., Gradstein, F.M., Schmitz, J.G.O.D., Ogg, G.M., 2012. Chapter 29-The Neogene Period. The Geologic Time Scale. Elsevier, Boston, pp. 923-978.

Hinschberger, F., Malod, J.-A., Réhault, J.-P., Villeneuve, M., Royer, J.-Y., Burhanuddin, S., 2005. Late Cenozoic geodynamic evolution of eastern Indonesia. Tectonophysics 404 (1-2), 91-118.

Hopley, D., 2005. Coral Reefs, Emerged. Encyclopedia of Coastal Science, pp. 349-352.

Johnson, M.E., Libbey, L.K., 1997. Global review of Upper Pleistocene (Substage 5e) Rocky Shores: tectonic segregation, substrate variation and biological diversity. J. Coast Res. 13 (2), 297-307.

Jouannic, C., Hoang, C.-T., Soepri Hantoro, W., Delinom, R.M., 1988. Uplift rate of coral reef terraces in the area of Kupang, West Timor: preliminary results. Palaeogeogr. Palaeoclimatol. Palaeoecol. Quat. Coast. Chang. 68 (2-4), 259-272.

Kuenen, P.H., 1933. The formation of the atolls in the Toekang-Besi-group by subsidence. Proc. K. Nederl. Akad. van Wet. Amst. 36, 331-336.

Lajoie, K.R., 1986. Coastal Tectonics. Active Tectonic. National Academic Press, Washington D, C, pp. 95-124. N. A. Press.

Lambeck, K., Purcell, A., Dutton, A., 2012. The anatomy of interglacial sea levels: the relationship between sea levels and ice volumes during the Last Interglacial. Earth Planet Sci. Lett. 315-316, 4-11.

Lambeck, K., Rouby, H., Purcell, A., Sun, Y., Sambridge, M., 2014. sea level and global ice volumes from the last glacial maximum to the Holocene. Proc. Natl. Acad. Sci. Unit. States Am. 111 (43), 15296-15303.

Lecolle, J.F., Bokilo, J.E., Bernat, M., 1990. Quaternary uplift and tectonism of the Ile d'Efaté, New Hebrides (Vanuatu) island arc: dating of uplifted terraces by the U/ Th method. Mar. Geol. 94 (3), 251-270.

Lisiecki, L.E., Raymo, M.E., 2005. A Pliocene-Pleistocene stack of 57 globally distributed benthic delta 18 O records. Paleoceanography 20, PA1003.

Ludwig, K.R., Szabo, B.J., Moore, J.G., Simmons, K.R., 1991. "Crustal subsidence rate off Hawaii determined from $234 \mathrm{U} / 238 \mathrm{U}$ ages of drowned coral reefs. Geology 19 (2), 171-174.

Lyell, C., 1830. Principles of Geology, Being an Attempt to Explain the Former Changes of the Earth's Surface, by Reference to Causes Now in Operation. John Murray, London.

Major, J., Harris, R., Chiang, H.-W., Cox, N., Shen, C.-C., Nelson, S.T., Prasetyadi, C., Rianto, A., 2013. Quaternary hinterland evolution of the active Banda Arc: surface uplift and neotectonic deformation recorded by coral terraces at Kisar, Indonesia. J. Asian Earth Sci. 73 (0), 149-161.

Mann, T., Rovere, A., Schene, T., Klicpera, A., Stocchi, P., Lukman, M., Westphal, H., 2016. The magnitude of a mid-Holocene sea-level high-stand in the Strait of Makassar. Geomorphology 257, 155-163.

Merritts, D., Eby, R., Harris, R., Edwards, R.L., Chang, H., 1998. Variable rates of Late Quaternary surface uplift along the Banda Arc-Australian plate collision zone, eastern Indonesia. Coastal Tectonics. I. S. Stewart and C. Vita-Finzi. London. Geol. Soc. Spec. Publ. 146, 213-224.

Milne, G.A., Long, A.J., Bassett, S.E., 2005. Modelling Holocene relative sea-level observations from the caribbean and south America. Quat. Sci. Rev. 24 (10-11), 1183-1202.

Mitrovica, J.X., Milne, G.A., 2003. On post-glacial sea-level: I. General theory. Geophys. J. Int. 154, 253-267.

Molnar, P., Cronin, T.W., 2015. Growth of the Maritime continent and its possible contribution to recurring ice ages. Paleoceanography 30 (3), 196-225.

Montaggioni, L., Braithwaite, C.J.R., 2009. Quaternary Coral Reef Systems : History, Development Processes and Controlling Factors. Elsevier, Amsterdam.

Montaggioni, L.F., Richard, G., Bourrouilh-Le Jan, F., Gabrie, C., Humbert, L., Monteforte, M., Naim, O., Payri, C., Salvat, B., 1985. Geology and marine biology of Makatea, an uplifted atoll, tuamotu archipelago, central pacific ocean. J. Coast Res. 165-171.

Murray-Wallace, C., Woodroffe, C., 2014. Quaternary Sea Level : a Global Perspective. Cambridge University Press, Cambridge.

Neef, G., McCulloch, M.T., 2001. Pliocene-quaternary history of Futuna island, south Vanuatu, southwest pacific. Aust. J. Earth Sci. 48, 805-814.

Nugraha, A.M.S., Hall, R., 2018. Late cenozoic palaeogeography of Sulawesi, Indonesia. Palaeogeogr. Palaeoclimatol. Palaeoecol. 490, 191-209.

Pedoja, K., Husson, L., Regard, V., Cobbold, P.R., Ostanciaux, E., Johnson, M.E., Kershaw, S., Saillard, M., Martinod, J., Furgerot, L., Weill, P., Delcaillau, B., 2011. Relative sea-level fall since the last interglacial stage: are coasts uplifting worldwide? Earth Sci. Rev. 108 (1-2), 1-15.

Pedoja, K., Husson, L., Johnson, M.E., Melnick, D., Witt, C., Pochat, S., Nexer, M., Delcaillau, B., Pinegina, T., Poprawski, Y., Authemayou, C., Elliot, M., Regard, V. Garestier, F., 2014. Coastal staircase sequences reflecting sea-level oscillations and tectonic uplift during the Quaternary and Neogene. Earth Sci. Rev. 132 (0), $13-38$.

Pigram, C.J., Supandjono, S.J.B., 1985. Origin of the Sula platform, eastern Indonesia. Geology 13 (4), 246-248.

Pillans, B., Gibbard, P., Gradstein, F.M., Schmitz, J.G.O.D., Ogg, G.M., 2012. Chapter 30-The Quaternary Period. The Geologic Time Scale. Elsevier, Boston, pp. 979-1010.

Pirazzoli, P.A., 2005a. Marine terraces. Encyclopedia of Coastal Science. Springer, pp. 632-633.
Pirazzoli, P.A., 2005b. In: Schwartz, M.L. (Ed.), Sea-level Indicators, Geomorphic Encyclopedia of Coastal Science. Springer Netherlands, Dordrecht, pp. 836-838.

Pirazzoli, P.A., 1994. In: Carter, R.W.G., Woodroffe, C.D. (Eds.), Tectonic Shorelines. Coastal Evolution : Late Quaternary Shoreline Morphodynamics. Cambridge University Press, Edimburgh, p. 517.

Pirazzoli, P.A., Radtke, U., Hantoro, W.S., Jouannic, C., Hoang, C.T., Causse, C., Best, M.B., 1991. Quaternary raised coral-reef terraces on Sumba Island, Indonesia. Science 252 (5014), 1834-1836.

Pirazzoli, P.A., Radtke, U., Hantoro, W.S., Jouannic, C., Hoang, C.T., Causse, C., Best, M.B., 1993. A one million-year-long sequence of marine terraces on Sumba Island, Indonesia. Mar. Geol. 109 (3-4), 221-236.

Puga-Bernabéu, Á., Webster, J.M., Braga, J.C., Clague, D.A., Dutton, A., Eggins, S. Fallon, S., Jacobsen, G., Paduan, J.B., Potts, D.C., 2016. Morphology and evolution of drowned carbonate terraces during the last two interglacial cycles, off Hilo. NE Hawaii Mar. Geol. 371, 57-81.

Radtke, U., Grün, R., Schwarcz, H.P., 1988. Electron spin resonance dating of the Pleistocene coral reef tracts of Barbados. Quat. Res. 29 (3), 197-215.

Rohling, E.J., Grant, K., Bolshaw, M., Roberts, A.P., Siddall, M., Hemleben, C. Kucera, M., 2009. Antarctic temperature and global sea level closely coupled over the past five glacial cycles. Nat. Geosci. 2, 500-504.

Rovere, A., Raymo, M.E., Vacchi, M., Lorscheid, T., Stocchi, P., Gomez-Pujol, L., Harris, D.L., Casella, E., O'Leary, M.J., Hearty, P.J., 2016. The analysis of last interglacial (MIS 5e) relative sea-level indicators: reconstructing sea-level in a warmer world. Earth Sci. Rev. 159, 404-427.

Roosmawati, N., Harris, R., 2009. Surface uplift history of the incipient Banda arccontinent collision: Geology and synorogenic foraminifera of Rote and Savu Islands, Indonesia. Tectonophysics Arc-continent Collision 479 (1e), 95-110.

Satyana, A.H., Purwaningsih, M.E.M., 2011. Collision of microcontinents with eastern Sulawesi: records from uplifted reef terraces and proven-potential petroleum plays. In: 35th Annual Convention and Exhibition. IPA.

Schellmann, G., Radtke, U., 2004. A revised morpho- and chronostratigraphy of the Late and Middle Pleistocene coral reef terraces on Southern Barbados (West Indies). Earth Sci. Rev. 64 (3-4), 157-187.

Schwartz, M., 2005. Encyclopedia of Coastal Science. Springer Science \& Business Media.

Shackleton, N.J., 1987. Oxygen isotopes, ice volume and sea level. Quat. Sci. Rev. 6 183-190.

Shakun, J.D., Lea, D.W., Lisiecki, L.E., Raymo, M.E., 2015. An 800-kyr record of global surface ocean $\hat{1} 180$ and implications for ice volume-temperature coupling Earth Planet Sci. Lett. 426, 58-68.

Shennan, I., Horton, B., 2002. Holocene land- and sea-level changes in Great Britain. J. Quat. Sci. 17 (5-6), 511-526.

Siddal, M., Chappell, J., Potter, E.-K., 2006. In: Sirocko, F., Claussen, M., Sanchez Goñi, M.F., Litt, T. (Eds.), Eustatic Sea Level during Past Interglacials. The Climate of Past Interglacials. Elsevier, Amsterdam, pp. 75-92.

Speed, R.C., Cheng, H., 2004. Evolution of marine terraces and sea level in the last interglacial, Cave Hill, Barbados. Geol. Soc. Am. Bull. 116 (1-2), 219-232.

Spratt, R.M., Lisiecki, L.E., 2016. A Late Pleistocene sea level stack. Clim. Past 12 (4), 1079

Stirling, C.H., Esat, T.M., Lambeck, K., McCulloch, M.T., 1998. Timing and duration of the Last Interglacial: evidence for a restricted interval of widespread coral reef growth. Earth Planet Sci. Lett. 160 (3-4), 745-762.

Stirling, C.H., Esat, T.M., Lambeck, K., McCulloch, M.T., Blake, S.G., Lee, D.-C., Halliday, A.N., 2001. Orbital forcing of the marine isotope stage 9 interglacial. Science 291 (5502), 290-293.

Stoddart, D.R., Spencer, T., 1987. Rurutu reconsidered : the development of Makatea topography in the Austral islands. Atoll Res. Bull. 297, 1-19.

Sumosusastro, P.A., Tjia, H.D., Fortuin, A.R., Van Der Plicht, J., 1989. Quaternary reef record of differential uplift at Luwuk, Sulawesi East Arm, Indonesia. Neth. J. Sea Res. 24 (2-3), 277-285.

Szabo, B.J., Moore, J.G., 1986. Age of -360-m reef terrace, Hawaii, and the rate of late Pleistocene subsidence of the island. Geology 14 (11), 967-968.

Thompson, W.G., Goldstein, S.L., 2005. Open-system coral ages reveal persistent suborbital sea-level cycles. Science 308 (5720), 401-404.

Thompson, W.G. Spiegelman, M.W., Goldstein, S.L., Speed, R.C., 2003. An opensystem model for U-series age determinations of fossil corals. Earth Planet Sci. Lett. 210 (1-2), 365-381.

Tjia, H.D., Fujii, S., Kigoshi, K., Sugimura, A., 1974. Late Quaternary uplift in eastern Indonesia. Tectonophysics 23 (4), 427-433.

Tjia, H.D., Fujii, S., Kigoshi, K., Sugimura, A., Zakaria, T., 1972. Radiocarbon dates of elevated shorelines, Indonesia and Malaysia. Part 1. Quat. Res. 2 (4), 487-495.

Tomascik, T., 1997. The Ecology of the Indonesian Seas. Oxford University Press.

van de Plassche, O., 1986. Sea-level Research : a Manual for the Collection and Evaluation of Data. Geo Books, Norwich, UK.

Verbeek, R.D.M., 1908. Rapport sur les Moluques: Reconnaissances géologiques dans la partie orientale de l'Archipel des Indes Orientales Néerlandaises (Batavia, Imprimerie de l'état).

Waelbroeck, C., Labeyrie, L.D., Michel, E., Duplessy, J.C., McManus, J.F., Lambeck, K., Balbon, E., Labracherie, M., 2002. Sea-level and deep water temperature changes derived from benthic foraminefera isotopic records. Quat. Sci. Rev. 21, $295-305$.

Ward, W.T., Ross, P.J., Colquhoun, D.J., 1971. Interglacial high sea levels - an absolute chronology derived from shoreline elevations. Palaeogeogr. Palaeoclimatol. Palaeoecol. 9 (2), 77-99.

Webster, J.M., Braga, J.C., Clague, D.A., Gallup, C.D., Hein, J.R., Potts, D.C., Renema, W. 
Riding, R., Riker-Coleman, K.E., Silver, E., Wallace, L.M., 2009. Coral reef evolution on rapidly subsiding margins. Global Planet. Change 66, 1129-1148.

Woodroffe, C.D., Horton, B.P., 2005. Holocene sea-level changes in the Indo-Pacific. J. Asian Earth Sci. 25, 29-43.

Yildirim, C., Melnick, D., Ballato, P., Schildgen, T.F., Echtler, H., Erginal, A.E., Kayak, N.,
Strecker, M.R., 2013. Differential uplift along the northern margin of the Central Anatolian Plateau: inferences from marine terraces. Quat. Sci. Rev. 81, 12-28. Zachos, J.C., Dickens, G.R., Zeebe, R.E., 2008. An early Cenozoic perspective on greenhouse warming and carbon-cycle dynamics. Nature 451 (7176), 279-283. 